\title{
The Alaska Bowhead Problem: A Commentary
}

\author{
EDWARD MITCHELL ${ }^{1}$ and RANDALL R. REEVES ${ }^{1.2}$
}

\begin{abstract}
The continued removal of individuals from the depleted Bering Sea stock of bowhead whales (Balaena mysticetus) by Alaskan Eskimos constitutes a risk of unknown magnitude to this last concentrated remnant of a once abundant, widely distributed species. The principal international forum for discussions of scientific, technical, management, social, and political aspects of the Bowhead Problem has been the International Whaling Commission. These discussions have been plagued by a lack of agreed definitions of terminology and by the inadequacy of historical and technical data.

We trace the origins of the Bowhead Problem, define the terms necessary for a rigorous discussion of "aboriginal" and "subsistence" whale fisheries, examine the biological, nutritional, and social dimensions of the Alaskan whale hunt, and assess the relationship between the present-day whale hunting methods and traditional values.

We accept the best scientific analyses available, which indicate that the only safe course for this bowhead stock is protection from any form of hunting. However, if a hunt continues for political reasons, then we conclude that a return to the traditional hunting method of fastening to the whale with a harpoon, line, and float should precede or coincide with any attempt to kill the whale. This return to the traditional method would reduce the struck-but-lost rate significantly. We also conclude that there are few, if any, specific products taken exclusively from the bowhead whale that are necessary to support the material culture of the Alaskan Eskimos. Other wildlife, including the gray whale (Eschrichtius robustus), has been hunted in the past as a nutritional alternative to the bowhead. Increased reliance on the gray whale would reduce hunting pressure on the bowhead and at the same time contribute to the preservation of the whaling culture.

If bowhead whaling is to be continued in order to satisfy "cultural needs," then we believe that only one bowhead whale at each village with a long tradition of whaling can be justified.
\end{abstract}

\section{INTRODUCTION}

The bowhead whale (Balaena mysticetus) (Fig. 1) and the Alaskan Eskimo have co-existed for many centuries. Much of the early human culture along the shores of the Bering and Chukchi seas was organized around the whale hunt. The people grew to depend on whales not only for food, heat, and shelter, but also as a focus of celebration, ritual, and social order. The large population of bowhead whales, numbering up to 18000 in the mid-19th century (Anon., 1978), was probably little affected by the Eskimo subsistence fishery. However, in 1848 Captain Thomas Roys worked the first American whaleship through Bering Strait and opened up the commercial pelagic whale fishery in the Arctic Ocean (Scammon, 1874). Although this fishery ended in about 1914 (Bockstoce and Botkin, 1980a), the Eskimos continued hunting what was left of the bowhead population (Marquette, 1979), using methods and equipment acquired from the Yankee whalers (Durham, 1974).

\footnotetext{
'Arctic Biological Station, 555 St. Pierre Blvd., Ste. Anne de Bellevue, Québec, Canada H9X 3R4

'Supported by a grant from People's Trust for Endangered Species, Guildford, Surrey, England.
} 


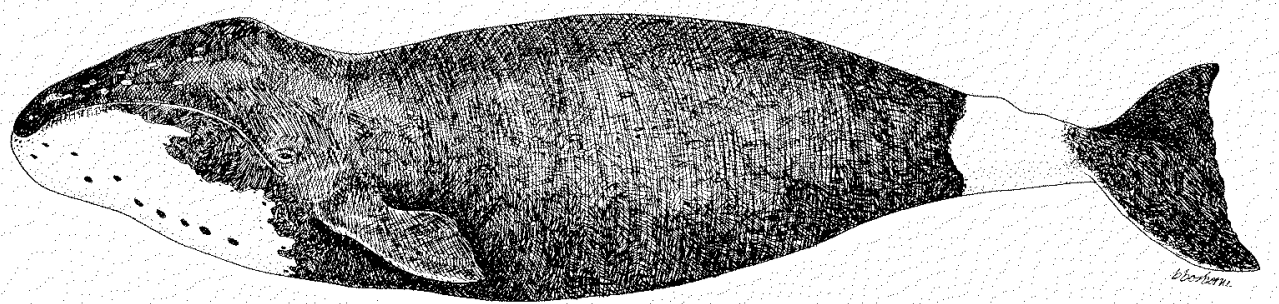

FIG. 1. The Greenland right whale, or bowhead whale, Balaena mysticetus, a circumpolar inhabitant of the Northern Hemisphere. (Drawing by B. Osborne)

The passage of the Land Claims Settlement Act in 1971 and the stepped-up pace of industrial development in Alaska meant that the economy of North Slope villages became increasingly cash-oriented. As one ethnologist put it, the funds needed to outfit a crew and go whaling "suddenly were within reach of any ambitious Eskimo" (Bockstoce, 1977). With the near-doubling of the number of crews, an increase in the landed catch, and reports of high struck-but-lost rates, the hunt attracted the concerned attention of the International Whaling Commission (IWC).

Every year since 1977 the IWC's Scientific Committee has recommended a zero catch for the bowhead in Alaska. This action has created a crisis that appears to be far from resolved. As an often effective voice for the reduction of excessive whaling quotas and establishment of various protective measures over the years, the U.S. has not made itself popular with some whaling countries. Now it is U.S. citizens, rather than Japanese, Russian, or Norwegian nationals, who threaten the effectiveness of international whaling regulation. What is at stake is the survival of a once abundant, widely distributed whale species, and of an ancient, highly specialized human civilization. Whether the IWC can itself survive the strain imposed by the bowhead controversy remains to be seen.

Activities associated with oil and gas extraction from the North have added a new dimension to the problem. Industrial development will continue to affect profoundly the way of life of the Eskimos and the habitat of the bowhead. As the IWC attempts to develop procedures for non-commercial whaling, Alaskan Eskimos and the whales they hunt are likely to be among the first subjects of a new order in natural resource conservation policy.

The purposes of this essay are to: (1) describe the context in which the Bowhead Problem has developed, (2) propose definitions of some key terms, and (3) offer a set of alternatives that would at once reduce from present levels the biological risk of extinction to the bowhead and allow for the preservation of a whaling tradition in Alaska. The bowhead has a future only as long as native whalers exercise restraint, and there certainly can be no culturally significant bowhead hunt if most, or all, of the whales are gone. tion legislation. Governments have been reluctant to restrict subsistence hunting 
by aboriginal people, even when the targets of such hunting are endangered species. Clauses in the U.S. - Canada Convention for the protection of Migratory Birds, the multinational Interim Convention on the Conservation of North Pacific Fur Seals, the International Convention for the Regulation of Whaling (1931), and the International Convention for the Regulation of Whaling (1946) with its Schedule of Whaling Regulations (amended annually) all confer on native groups a privileged status.

The Convention for the Regulation of Whaling (1931) was explicit in its Article 3:

"The present Convention does not apply to aborigines dwelling on the coasts of the territories of the High Contracting Parties provided that:

(1) They only use canoes, pirogues or other exclusively native craft propelled by oars or sails;

(2) They do not carry firearms;

(3) They are not in the employment of persons other than aborigines;

(4) They are not under contract to deliver the products of their whaling to any third person."

Canada, Denmark, and the U.S. (but not Japan and the U.S.S.R.) were parties to this convention. Because Alaskan Eskimos had become familiar with firearms as early as the 19th century and incorporated the shoulder gun and bomb lance into their bowhead whaling technology, signing of this Convention meant that the U.S. government "was either uninformed on Eskimo weaponry, chose to ignore such knowledge, or perhaps went along with romantic ideas of aboriginal practice with the thought that the problem was of little consequence" (Durham, 1974).

The International Convention for the Regulation of Whaling (1946), which superseded the 1931 convention and created the 22-member International Whaling Commission (IWC), ignored entirely the question of methods used by "aboriginal" whalers. Section 2 of its original schedule stated:

"It is forbidden to take or kill gray whales or right whales, except when the meat and products of such whales are to be used exclusively for local consumption by the aborigines."

This so-called "aboriginal exemption clause" was amended in 1965 to allow contracting governments to take whales "on behalf of" aborigines. Although the proposal for this change was made by the U.S. Commissioner and seconded by the Dutch Commissioner "in order to avoid abuse of the rights of aborigines by commercial interests," it has been especially relevant to activities in the Soviet Arctic. There a government-sponsored catcher boat takes 150-200 gray whales each year and delivers the carcasses to Siberian aborigines (Anon., 1979a).

In addition, Section 6 on the protection of humpback whales (Megaptera novaeangliae) was amended in 1961 to allow West Greenlanders to continue taking up to ten per year, provided that catcher boats of less than 50 registered tons were used in the capture. A minimum length limit for whales of 35 feet (10.7 m) was applied to this fishery in 1973.

The present wording of the aboriginal exemption clause (as amended in July 1979) is: 
"Notwithstanding the provisions of paragraph 9 [re: the classification of whale stocks] the taking of 10 humpback whales not below 35 feet $(10.7 \mathrm{~m})$ in length, per year is permitted in Greenland waters provided that whale catchers of less than 50 gross register tonnage are used for this purpose, and the taking of gray whales, and of bowhead whales from the Bering Sea stock, by aborigines or a Contracting Government on behalf of aborigines is permitted, but only when the meat and products of such whales are to be used exclusively for local consumption by the aborigines and further provided, with respect to the Bering Sea stock of bowhead whales that:

(a) in 1980, hunting shall cease when either 26 have been struck or 18 landed,

(b) it is forbidden to strike, take or kill calves or any bowhead whale accompanied by a calf."

Surely it was not the intent of the drafters of either convention to allow unmonitored and unregulated "aboriginal" whaling to lead to extinction of species, or even populations of whales, especially in view of the explicit statements in the preamble to the 1946 convention concerning the "safeguarding for future generations the great natural resources represented by the whale stocks." Undoubtedly the most pressing problem at the time was the rationalization of commercial whaling; the highly local and presumably modest impact of native whaling had to await the attentions of a later generation.

ORIGINS OF THE CRISIS

Superficially, the IWC's move to regulate the bowhead fishery in 1977 seemed an abrupt departure from its neglectful attitude toward native whaling until then. In fact, it was the result of a growing awareness among cetologists that whaling pressure on the stock was increasing, and that there was a real possibility of extinction from continued hunting.

At the 24th annual meeting of the IWC in 1972, the Scientific Committee requested better information on the aboriginal kill of bowhead, gray, and other whales in Greenland, Alaska, and the Soviet Arctic, and specifically asked the Commission to urge the U.S. to take steps to reduce the loss rate in its arctic whale fishery (Anon., 1973:34). The Committee's expressions of concern became more explicit, and more emphatic, with each succeeding year. In 1976 the Committee had evidence in-hand showing a clearcut increase in whaling effort (Marquette, 1976). The committee strongly endorsed a logbook study designed to estimate pre-exploitation population size, and marking studies to assess survival rates of whales that had been struck but lost. Besides calling for expanded research and monitoring of catches; the Committee specifically urged that:

". . . necessary steps be taken to limit the expansion of the fishery and to reduce the loss rate of struck whales (without increasing total take)" (Anon., 1977a).

At the June 1977 meeting in Canberra, Australia, the Committee had two new and compelling arguments to consider. A preliminary review of published data 

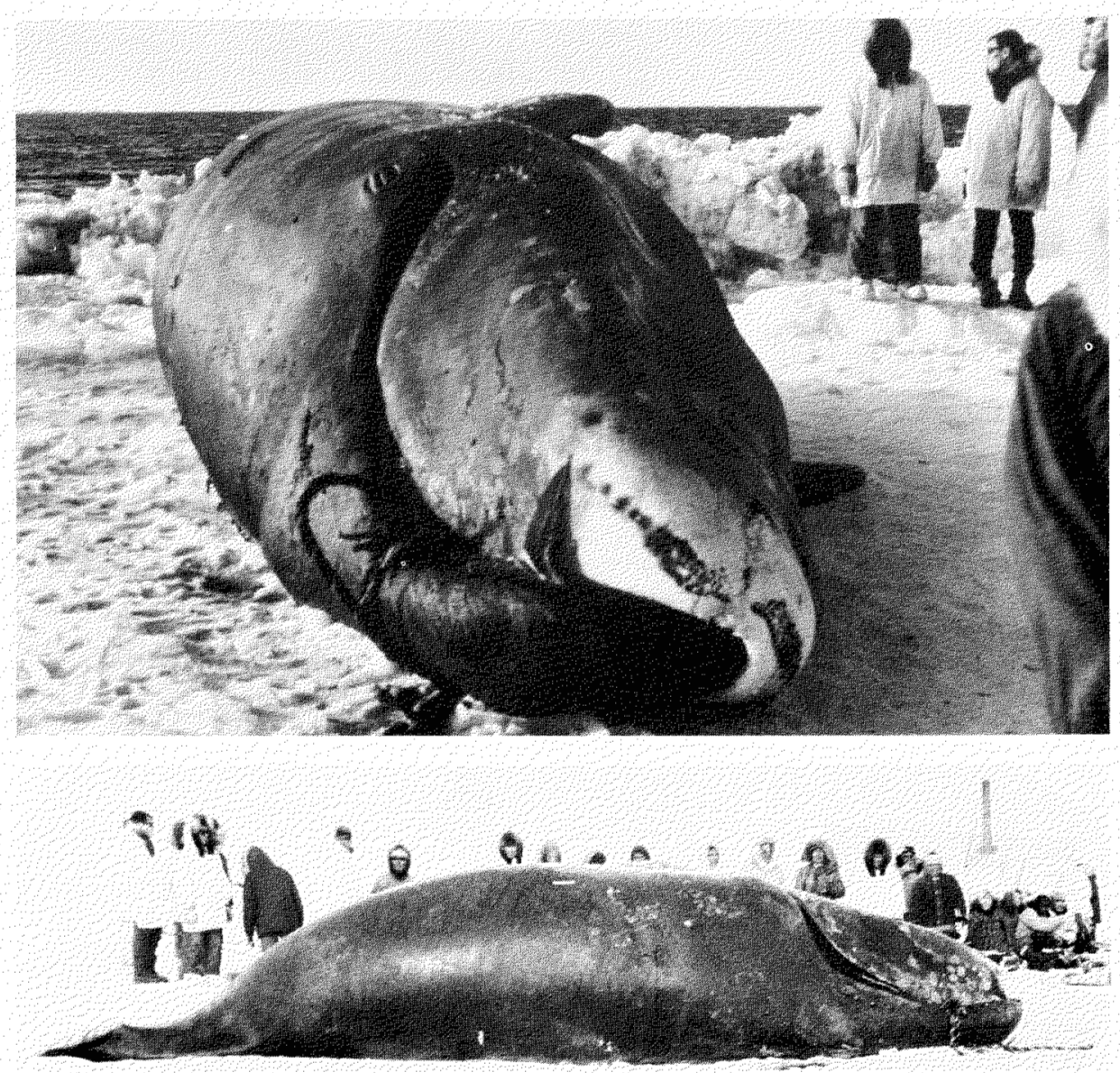

FIG. 2. A small bowhead whale, an "ingutuk," $7.92 \mathrm{~m}$ in length with a maximum girth of $6.14 \mathrm{~m}$, taken at Point Hope, Alaska, on May 28, 1967, by Amos Lane's crew (harpooner Jacob Lane). (Photos by D. C. Foote, top; E. D. Mitchell, bottom)

showed that there were probably at least 18000 bowheads in the Bering Sea stock prior to its intensive commercial exploitation which began about 1860 (Mitchell, 1977). Using the best current population estimate of 600-2000, this implied a reduction to 6-10 percent of initial stock size (Anon., 1978). In addition, U.S. representatives indicated that 48 whales had been killed and landed in 1976, 26 (not including the fall season) in 1977, with 43 struck-but-lost in 1976, and 79 in 1977 (Anon., 1978). The landed harvest had more than doubled from 12.9 per year in the 1960's to 29.5 in the period 1973-1977 (Marquette, 1979).

In recommending the cessation of bowhead whaling in Alaska (Fig. 2), the Scientific Committee was attacking a very complex subject. Inuit in Canada had persisted in hunting bowhead whales in the Eastern Arctic as recently as the mid-1970's (Mitchell and Reeves, in press a). West Greenland fishermen, using mounted harpoon cannons, had increased their average reported annual harvest of protected humpback whales from 2.2 in the period 1960-1972 to 9.3 in the 
period 1973-1976 (Kapel, 1979), and they far exceeded even their special annual allocation of ten by taking 20 in 1978 (Anon., 1980a). Antillean whalers in the Caribbean continued to take a few humpbacks from what may be the same stock on its winter calving and nursery grounds (Winn et al., 1975). Finally, in addition to the gray whales taken each year by a modern Soviet catcher boat for northern natives, a few bowheads have been taken off Siberia in some years (Anon., 1979 a). In view of these facts, the Scientific Committee resolved to consider at its next meeting the general issue of the impact of aboriginal whaling on protected stocks.

\section{RESPONSE OF THE INTERNATIONAL WHALING COMMISSION}

The IWC and the international conservation community were ill-prepared for the crisis now before them. The failure to collect scientific data on whales taken in "aboriginal" fisheries meant that the harvest impact could not be measured. For the Bering Sea stock of bowheads, an intensive, expensive program of research was undertaken to compensate for the lack of long-term monitoring (Marquette, 1979; Braham et al., 1979). Nevertheless, the debate continues in what can best be described as an information vacuum.

The structure of the IWC, and historical precedent, preclude routine acceptance of the Scientific Committee's recommendations. Bearing in mind its charge not only to "provide for the proper conservation of whale stocks" but also to "make possible the orderly development of the whaling industry," the Commission must consider other factors as well as the advice of its panel of scientific experts before setting quotas and establishing regulations. In the case of aboriginal whaling, these other factors are nutritional, cultural, economic, political, and technical in nature. They are clearly outside the expertise presently represented in the Scientific Committee and, with the exception perhaps of economic and political considerations, probably beyond the ken of the commissioners as well.

Lacking suitable machinery for gathering and evaluating non-biological data, the Commission decided at its annual meeting in 1978 to charge a working group of its Technical Committee:

“. . . to examine the entire aboriginal whaling problem and develop proposals for a regime for the aboriginal bowhead hunt in Alaska and if appropriate a regime or regimes for other aboriginal hunts" (Anon., 1979b).

On February 5-9, a Panel Meeting of Experts on Aboriginal/Subsistence Whaling was held in Seattle, Washington, to prepare background material and advice for the Technical Committee's Working Group on Aboriginal/ Subsistence Whaling (Anon., 1979c). The main findings of the Seattle meeting were as follows:

1) On biological grounds, the only safe course is to provide complete protection for bowhead whales until their population has made a satisfactory recovery. 2) On nutritional grounds, the bowhead whale offers nothing essential to the Eskimo diet that cannot be acquired from a wide variety of other sources. 3) There are a number of alternative wildlife resources within reach of whaling villages that could replace bowhead whales in the Eskimo diet. These include 
seals, walruses, gray whales, birds, fish, and possibly polar bears and caribou. 4) Any forced change in whaling practices will have a major impact on the cultural well-being of North Alaskan Eskimos. 5) Proposed regulations or other control measures should be subject to consultation and close cooperation with leaders of the Eskimo community.

Two management initiatives, in addition to the establishment of a bowhead catch quota, were supported: 1) recognition of the legitimacy of using modern technology in the conduct of subsistence whaling, and improvement of weapons in order to reduce the struck-but-lost rate; and 2) further investigation of the desirability and feasibility of replacing bowhead whales with gray whales in the Eskimo catch.

The panel meeting's examination of inter-disciplinary questions arising from the IWC's request for management advice was less than rigorous. There were no agreed working definitions of aboriginal and subsistence whaling. Although cultural anthropology is admittedly a non-quantitative science, the Cultural Panel should have addressed more fully such questions as: 1) Has there been a real increase in hunting pressure on bowheads during the past three decades? 2) Are there unique items important to the material culture of Alaskan whaling villages that can only be acquired from bowhead whales? 3) Are there appreciable differences in the degree to which individual whaling villages maintain their links with the past? and 4) How does the present-day Eskimo whaling culture differ from that of former times in quantitative terms?

The various reports of the panels and working groups are valuable documents. However, such ad hoc handling of non-biological data is inadequate to the Commission's needs. Creation of a permanent committee, parallel to the Scientific Committee, with a mandate to gather and evaluate non-biological technical data is, in our opinion, long overdue.

The Technical Committee's Working Group on Subsistence/Aboriginal Whaling met in Washington, D.C., on 3-5 April 1979 to develop a regime for the aboriginal bowhead hunt in Alaska and, if appropriate, one for other aboriginal hunts as well. Its proposed scheme was not implemented by the Commission at its July 1979 meeting.

\section{THE U.S. GOVERNMENT'S RESPONSE}

The controversy in the U.S. resulting from the proposed zero catch quota for bowhead whales led to a series of hearings in Alaska and Washington, D.C., and the hasty preparation of a two-volume environmental impact statement (Anon., 1977b). The eventual decision by the U.S. government to resist the IWC Scientific Committee's recommendation has badly tarnished its reputation as an advocate of whale conservation (Storro-Patterson, 1979).

Two domestic laws have complicated the U.S. position on bowhead-related issues. The Marine Mammal Protection Act of 1972 was passed by Congress only after the Alaskan lobby had been assured that native hunting rights would be maintained (Anon., 1972). The Act exempts "any Indian, Aleut, or Eskimo who dwells on the coast of the North Pacific Ocean or the Arctic Ocean" from the general prohibition on the taking of marine mammals. It does require that 
their hunting be done only "for subsistence purposes" or "for purposes of creating and selling authentic native articles of handicrafts and clothing," and that it not be "accomplished in a wasteful manner." It is important to note that native whaling is subject to further regulation under the Marine Mammal Protection Act if the stock being fished is judged to be "depleted" by the Secretary of Commerce.

The Endangered Species Act of 1973 (and as amended in 1978) went no further toward protecting the bowhead from native hunting than had any previous international agreement or domestic law. Indians, Aleuts, and Eskimos who are Alaska natives and reside in Alaska, as well as non-native permanent residents of native villages in Alaska, are allowed to continue hunting for endangered or threatened species so long as "such taking is primarily for subsistence purposes" and is not done in a "wasteful manner." Subsistence, as defined in this act, encompasses the "selling of any portion of fish or wildlife in native villages and towns in Alaska for native consumption within native villages or towns." In addition, non-edible byproducts, including "authentic native articles of handicrafts and clothing," can be sold in interstate commerce. Regulation of native whaling by the Secretary of Commerce is permitted only if the taking "materially or negatively affects the threatened or endangered species." We cannot imagine a situation in which a genuinely "endangered" species of large mammal would not be materially or negatively affected by an exploitation regime that removes, by killing or seriously wounding, more than the assumed sustained or replacement yield.

\section{SUMMARY OF THE BOWHEAD PROBLEM}

The Scientific Committee of the International Whaling Commission has determined that the depleted Bering Sea stock of bowhead whales is unable to sustain the existing rate of removals by the Alaskan Eskimo fishery, including a high landed catch and an even higher struck-but-lost component. The International Whaling Commission and domestic regulatory agencies in the U.S. have tried unsuccessfully to strike a balance between the biological risk of extinction and the socio-political consequences of attempting to regulate, or even stop, this controversial fishery.

Effective management has been frustrated by: 1) inadequacy of biological data concerning the stock; 2) lack of agreement on what constitutes aboriginal and subsistence whaling; 3 ) disagreement about the importance of bowhead whaling in the nutritional and cultural life of the Eskimo communities; and 4) general absence of legislative or bureaucratic means for addressing non-biological questions. Eskimo hunters have reacted to management initiatives defiantly. They have no evident history of self-imposed whale conservation practices, apart from the inherent efficiency of traditional whaling techniques. Local seasonal abundance of whales is interpreted by the Eskimos as adequate testimony to the health of the regional biological stock. 


\section{DEFINITIONS}

Without an agreed lexicon, those who debate the Bowhead Problem talk in vain. If key terms are defined, the participants can evaluate the non-commercial fisheries against a common set of standards - whether they be for bowhead, gray, humpback, sperm (Physeter macrocephalus), or any other of the great whales, and even the lesser sorts.

In Table 1 we present a list of key terms with proposed definitions. We make no pretense of being expert linguists or etymologists. What is important, in our view, is that parties to debate on the Bowhead Problem share a common understanding of the terms in this specific context. Our table of definitions is offered as a starting point for critical discussion.

Table 1. Proposed definitions.

\begin{tabular}{cc} 
Terms & Proposed Meaning \\
\hline
\end{tabular}

A. aboriginal whale fishery

By endemic (autochthonous) local people, for a period exceeding locally documented history, the products of the fishery being used locally.

WHO

B. non-aboriginal whale fishery

By people who can be of diverse heritage but who come together for the common purpose of capturing whales and processing whale products for personal consumption and/or monetary gain, for which the history is usually well documented.

A. local whale fishery

WHERE

B. regional whale fishery

1. primitive whaling

WHEN

2. 19th century whaling

3. modern whaling
- Conducted at or near the area of permanent occupancy of the group pursuing the fishery.

Conducted, at least in part, well outside the area of permanent occupancy of the group pursuing the fishery.

As developed in prehistoric times, carried out using implements and techniques associated with entrapment, driving and/or netting, the hand harpoon-line-drogue method, or poisoning or bacterial methods.

As developed in historic times, based on harpoon-fastline-open boat techniques, pursued from shore or from sailing mother ships, using a lance for the kill and oar- and/or wind-driven open boats.

As developed mainly since ca. 1860 , based on mechanical means of transport and the common application of firearms and explosives in the killing of whales. 
A. subsistence whale fishery

WHY

B. commercial whale fishery

1. traditional whaling

HOW

2. transitional whaling

3. mechanical whaling

a.) shore-based whale fishery

b.) pelagic whale fishery
Conducted by a cohesive community of people who have at least a partially non-cash economy, the products of the fishery being clearly intended for local consumption, a significant portion as human food.

Conducted by anyone for the main or ancillary purpose of selling one or more products in a cash economy.

With techniques and implements long fixed in the culture of the hunting group, which itself has a history of such whaling spanning many human generations, and largely depending on material cultural items gathered or produced locally (and exclusive of engines and explosives).

With traditional methods, but modified by introduction of such implements as firearms, explosive projectiles, and mechanized means of transport.

With techniques and implements centered on the use of explosives and engines, usually (but not always) involving deck-mounted cannons, explosive grenades, direct fastening to the whale, and diesel, gas or steam-powered boats and ships.

Conducted directly from land or ice, or by one or more vessels that catch the whales and deliver the carcasses for land-based processing.

Conducted by one or more vessels that catch the whales and process them on board, or deliver the carcasses to a floating processing plant.

\section{ABORIGINAL/SUBSISTENCE WHALE FISHERIES WORLDWIDE}

Despite its professed intention to do so (Anon., 1978), the IWC Scientific Committee has not conducted a review of the impact of aboriginal/subsistence whale fisheries on stocks around the world. At its annual meeting in 1978, a working document titled "Collection of Scientific Data from 'Aboriginal' Whale Fisheries" was tabled by one of us (E.D.M.), but it was not discussed or accepted for publication by the Commission. We strongly believe that the general review, as proposed by the Scientific Committee in 1977 (Anon., 1978), is essential and overdue. In order to give perspective to the Alaskan bowhead fishery and to stimulate discussion of the wider implications of its management, we have presented a tabular summary of worldwide fisheries for large whales 
Table 2. Existing fisheries for large whales that can be regarded as aboriginal, local, primitive, subsistence, or traditional.

\begin{tabular}{|c|c|c|c|c|c|c|c|}
\hline WHO & WHERE & WHAT & WHEN & WHY & HOW & CLASSIFICATION & SOURCES \\
\hline $\begin{array}{l}\text { West Greenlanders } \\
\text { of mixed European } \\
\text { and Eskimo } \\
\text { ancestry }\end{array}$ & $\begin{array}{l}\text { Along the west } \\
\text { coast of Greenland. }\end{array}$ & $\begin{array}{l}\text { A variety of small } \\
\text { cetaceans, ca. } \\
10(+) \text { humpbacks } \\
\text { and a few hundred } \\
\text { minkes per annum, } \\
\text { plus a few sperm, } \\
\text { fin, and possibly } \\
\text { other large whales. }\end{array}$ & $\begin{array}{l}\text { Balaenopterids } \\
\text { since the late } \\
1700 \text { 's, possibly } \\
\text { longer (bowheads } \\
\text { taken for hundreds, } \\
\text { perhaps thousands } \\
\text { of years, but not } \\
\text { hunted seriously } \\
\text { since 19th } \\
\text { century). }\end{array}$ & $\begin{array}{l}\text { For local } \\
\text { subsistence, mainly } \\
\text { meat at present. }\end{array}$ & $\begin{array}{l}\text { From cutters and } \\
\text { small fishing } \\
\text { vessels with } \\
\text { mounted whaling } \\
\text { cannons; small } \\
\text { cetaceans, } \\
\text { including minke } \\
\text { whales, by rifle } \\
\text { and harpoon from } \\
\text { small boats. }\end{array}$ & $\begin{array}{l}\text { Aboriginal, local, } \\
\text { modern, } \\
\text { subsistence, } \\
\text { transitional and } \\
\text { mechanical, } \\
\text { shore-based. }\end{array}$ & $\begin{array}{l}\text { Rink, 1877; Vibe, } \\
\text { 1967; Mitchell, } \\
\text { 1975; Kapel, 1975; } \\
\text { 1977a; 1977b; 1978; } \\
\text { 1979; Kapel and } \\
\text { Peterson, 1979. }\end{array}$ \\
\hline $\begin{array}{l}\text { Local fishermen of } \\
\text { Portuguese } \\
\text { ancestry. }\end{array}$ & $\begin{array}{l}\text { Coastal waters of } \\
\text { the Azores and } \\
\text { Madeira. }\end{array}$ & $\begin{array}{l}\text { Mainly sperm } \\
\text { whales of both } \\
\text { sexes, presently } \\
\text { some delphinids; } \\
\text { right whales taken } \\
\text { occasionally at } \\
\text { Madeira. }\end{array}$ & $\begin{array}{l}\text { Since early days of } \\
\text { pelagic open-boat } \\
\text { whaling from } \\
\text { sailing vessels - } \\
\text { possibly as early as } \\
\text { mid } 18 \text { th century. }\end{array}$ & $\begin{array}{l}\text { Oil and meat sold } \\
\text { commercially; } \\
\text { some by-products } \\
\text { (e.g. leather, } \\
\text { tendons) used } \\
\text { locally; scrimshaw } \\
\text { the basis of a } \\
\text { cottage industry. }\end{array}$ & $\begin{array}{l}\text { Open boats and } \\
\text { hand-harpooning; } \\
\text { recently motor } \\
\text { launches used to } \\
\text { tow whaling boats } \\
\text { within attacking } \\
\text { distance of whales. }\end{array}$ & $\begin{array}{l}\text { Non-aboriginal, } \\
\text { local, 19th century, } \\
\text { commercial, } \\
\text { traditional and } \\
\text { transitional, } \\
\text { shore-based. }\end{array}$ & $\begin{array}{l}\text { Clarke, 1954; 1956; } \\
\text { Venables, 1968; } \\
\text { Housby, 1971; } \\
\text { Maul and Sergeant, } \\
1977 ; \\
\text { Compton-Bishop et } \\
\text { al., } 1980 .\end{array}$ \\
\hline $\begin{array}{l}\text { Local inhabitants } \\
\text { of Caribbean } \\
\text { islands; of mixed } \\
\text { ancestry (mainly } \\
\text { African and } \\
\text { European). }\end{array}$ & $\begin{array}{l}\text { Coastal waters of } \\
\text { the Grenadines, } \\
\text { especially St. } \\
\text { Vincent, Bequia } \\
\text { and St. Lucia. }\end{array}$ & $\begin{array}{l}\text { Humpbacks } \\
\text { preferred at } \\
\text { Bequia, where } 5 \text { or } \\
\text { less, usually } \\
\text { females and young, } \\
\text { are taken per } \\
\text { annum; pilot } \\
\text { whales, sperm } \\
\text { whales and other } \\
\text { odontocetes most } \\
\text { important at St. } \\
\text { Vincent and St. } \\
\text { Lucia. }\end{array}$ & $\begin{array}{l}\text { Since 19th century, } \\
\text { when technology of } \\
\text { pelagic open-boat } \\
\text { whaling was } \\
\text { transferred to the } \\
\text { islanders. }\end{array}$ & $\begin{array}{l}\text { Meat of } \\
\text { humpbacks and } \\
\text { some odontocetes } \\
\text { sold and consumed } \\
\text { locally; much of oil } \\
\text { exported until } \\
\text { recently. }\end{array}$ & $\begin{array}{l}\text { Open (motor) boats } \\
\text { and } \\
\text { hand-harpooning; } \\
\text { small } \\
\text { deck-mounted } \\
\text { cannons used in } \\
\text { some areas. }\end{array}$ & $\begin{array}{l}\text { Non-aboriginal, } \\
\text { local, 19th century, } \\
\text { subsistence and } \\
\text { commercial, } \\
\text { transitional, } \\
\text { shore-based. }\end{array}$ & $\begin{array}{l}\text { Rathjen and } \\
\text { Sullivan, 1970; } \\
\text { Adams, 1971; 1975; } \\
\text { Caldwell and } \\
\text { Caldwell, 1975; } \\
\text { Winn et al., 1975; } \\
\text { Gaskin and Smith, } \\
\text { 1977; Fenger, 1913. }\end{array}$ \\
\hline
\end{tabular}




\begin{tabular}{|c|c|c|c|c|c|c|c|}
\hline $\begin{array}{l}\text { Inupiat and Tupik } \\
\text { people, some of } \\
\text { mixed } \\
\text { white-Eskimo } \\
\text { ancestry, in Alaska } \\
\text { and western } \\
\text { Canada; Chukchi, } \\
\text { Koryak, and } \\
\text { Eskimo people of } \\
\text { northeast Siberia.' }\end{array}$ & $\begin{array}{l}\text { Along Alaskan and } \\
\text { Canadian coasts of } \\
\text { Bering, Chukchi, } \\
\text { and Beaufort Seas; } \\
\text { along Siberian } \\
\text { coasts of Chukchi } \\
\text { and Bering Seas. }\end{array}$ & $\begin{array}{l}\text { Bowhead, gray, } \\
\text { minke, and beluga } \\
\text { whales in Alaska; } \\
\text { mainly belugas in } \\
\text { Canada; mainly } \\
\text { gray and beluga } \\
\text { whales, with a few } \\
\text { bowheads, in } \\
\text { Siberia. }\end{array}$ & $\begin{array}{l}\text { For at least a } \\
\text { thousand years, } \\
\text { possibly much } \\
\text { longer. }\end{array}$ & $\begin{array}{l}\text { Mainly local } \\
\text { consumption; some } \\
\text { barter of meat to } \\
\text { inland settlements; } \\
\text { baleen and some } \\
\text { bone of bowheads } \\
\text { used for } \\
\text { handicrafts in } \\
\text { cottage industry; } \\
\text { some baleen sold } \\
\text { intact } \\
\text { commercially. }\end{array}$ & $\begin{array}{l}\text { Open boats } \\
\text { propelled by hand } \\
\text { (or sail at St. } \\
\text { Lawrence Island) } \\
\text { in spring; } \\
\text { motorboats in fall; } \\
\text { darting gun (bomb } \\
\text { lance); shoulder } \\
\text { gun; belugas and } \\
\text { gray whales shot } \\
\text { with rifles; } \\
\text { block-and-tackle, } \\
\text { snowmobile, and } \\
\text { tractor for towing } \\
\text { and hoisting; } \\
\text { commercial catcher } \\
\text { boat used for } \\
\text { baleen whale } \\
\text { harvest in Soviet } \\
\text { Arctic. }\end{array}$ & $\begin{array}{l}\text { Aboriginal, local, } \\
\text { modern, } \\
\text { subsistence and } \\
\text { partially } \\
\text { commercial, } \\
\text { transitional and } \\
\text { mechanical, } \\
\text { shore-based. }\end{array}$ & $\begin{array}{l}\text { Heizer, 1938; 1968; } \\
\text { Van Valin, 1945; } \\
\text { Maher, 1960; } \\
\text { Maher and } \\
\text { Wilimovsky, 1963; } \\
\text { Johnson et al., } \\
\text { 1966; Davidson, } \\
\text { n.d.; Bockstoce, } \\
\text { 1976a; Marquette, } \\
\text { 1976; 1978; 1979; } \\
\text { Slwooko, 1977; } \\
\text { Anon., 1979a; } \\
\text { Steensby, 1917; O. } \\
\text { Schaefer letter in } \\
\text { Anon., 1979c; } \\
\text { Johnson et al., } \\
\text { 1980; Bogoras, } \\
\text { 1904-09. }\end{array}$ \\
\hline $\begin{array}{l}\text { Native } \\
\text { Polynesians. }\end{array}$ & $\begin{array}{l}\text { Near the Tonga } \\
\text { Islands, especially } \\
\text { Ha'Apai and } \\
\text { Vava'U. }\end{array}$ & $\begin{array}{l}\text { Humpback whales, } \\
\text { of which up to } 9 \\
\text { taken in one year } \\
\text { recently; mainly } \\
\text { pregnant females, } \\
\text { females with } \\
\text { calves, and calves. }\end{array}$ & $\begin{array}{l}\text { Since mid-19th } \\
\text { century. }\end{array}$ & $\begin{array}{l}\text { Meat and blubber } \\
\text { presumably } \\
\text { consumed locally. }\end{array}$ & $\begin{array}{l}\text { Open } \\
\text { boat-harpoon-fixed } \\
\text { line (or drogue?) } \\
\text { technique. }\end{array}$ & $\begin{array}{l}\text { Aboriginal, local, } \\
\text { 19th century, } \\
\text { subsistence, } \\
\text { traditional or } \\
\text { transitional, } \\
\text { shore-based. }\end{array}$ & $\begin{array}{l}\text { Ruhen, } 1966 \text {; } \\
\text { Cawthorn, } 1979 .\end{array}$ \\
\hline $\begin{array}{l}\text { Indigenous natives } \\
\text { of Indonesia. }\end{array}$ & $\begin{array}{l}\text { Around Timor } \\
\text { Archipelago, } \\
\text { mainly near } \\
\text { Lembata Island. }\end{array}$ & $\begin{array}{l}\text { Various small } \\
\text { cetaceans, perhaps } \\
\text { up to } 40 \text { sperm } \\
\text { whales, mainly } \\
\text { small individuals; } \\
\text { and occasionally } \\
\text { small } \\
\text { balaenopterids. }\end{array}$ & $\begin{array}{l}\text { From early times, } \\
\text { active in } 1899-1900 \\
\text { when visited by } \\
\text { Siboga Expedition. }\end{array}$ & $\begin{array}{l}\text { All products used } \\
\text { locally. }\end{array}$ & $\begin{array}{l}\text { In earlier times, } \\
\text { open boats and } \\
\text { hand-harpooning; } \\
\text { presently a vessel } \\
\text { with a mounted } \\
\text { cannon is used. }\end{array}$ & $\begin{array}{l}\text { Aboriginal, local, } \\
19 \text { th century and/or } \\
\text { modern. } \\
\text { subsistence, } \\
\text { transitional, } \\
\text { shore-based. }\end{array}$ & $\begin{array}{l}\text { Weber, 1902; 1923; } \\
\text { Barnes, 1974; John } \\
\text { Goodman, pers. } \\
\text { comm. }\end{array}$ \\
\hline
\end{tabular}

'We have followed Heizer (1938) in recognizing one whaling tradition along the shores of the Bering. Chukchi, and Beaufort seas, although we are well aware of the present-day differences in technology and utilization patterns within this region. 
that are considered to be, according to our definitions in Table 1 , some combination of aboriginal, local, primitive, subsistence, or traditional whaling (Table 2).

THE ALASKAN ESKIMO WHALING CULTURE

The Alaskan Eskimo whaling culture is ancient and complex. The taboos, songs, rituals, and festivities associated with the hunt formed a significant part of the social and religious life of whaling communities (Murdoch, 1892; Rainey, 1947; Spencer, 1959). Hierarchical relationships within the community were determined largely according to organization of the whaling crews - the umelik, or boat captain, being the closest thing in Eskimo society to a leader or chief.

Much of the yearly calendar of the North Slope Eskimos revolved around preparations for the whale hunt, its actual conduct, processing of the whales, and feasting. Although descriptions of early Eskimo whaling generally are not quantitative, Rainey (1947) attempted to outline the yearly cycle at Point Hope before 1900 .

During fall, dwellings and ceremonial structures were readied for winter, and various celebrations took place. Many of the ceremonies centered on the hope of ensuring success during the following spring whaling season. Little hunting was done in the fall, as the people usually had adequate caches of whale, walrus, seal, and caribou to last until the ice was safe for winter seal hunting. However, a fall hunt for bowheads apparently occurred at Point Hope in the days before commercial whaling (Rainey, 1947:263), and such a hunt has taken place more or less continuously at Barrow (Spencer, 1959:349).

"During all the winter months, from November to April, the daily task of every able-bodied man was to hunt seals from daylight until dark" (Rainey, 1947). The children and old people fished for crabs and "tomcod." Preparations for whaling were an under-current of life in winter. Wooden paddles and spear handles were scraped in January, and sealskin floats were constructed in February.

Before the first whales were sighted in late March or early April, the boats were made ready - if possible they were refitted with fresh sealskin coverings. Spring whaling and its elaborate attendant rituals occupied virtually all the people's energies until about the first of June. The season culminated with a grand feast and the joyful communal blanket-toss (Rainey, 1942).

Toward the end of spring whaling, certainly by late May and sometimes through early July, seal and bird hunting replaced whaling in importance. The open water of summer, from July onwards, allowed families to undertake camping and trading holidays. Food was readily available. White whales or belugas (Delphinapterus leucas) could be netted; birds were snared and their eggs gathered; some people fished; others hunted walruses hauled out on land. Caribou hunting was considered the most important summer occupation (Rainey, 1947).

More recent observations at Point Hope (pers. comm. to E.D.M. from the late D.C. Foote at Point Hope in 1967) and Wainwright (Nelson, 1969) suggest that this general pattern still holds. Notable changes have been made, however, in hunting technology (see below), and opportunities for salaried or wage employ- 


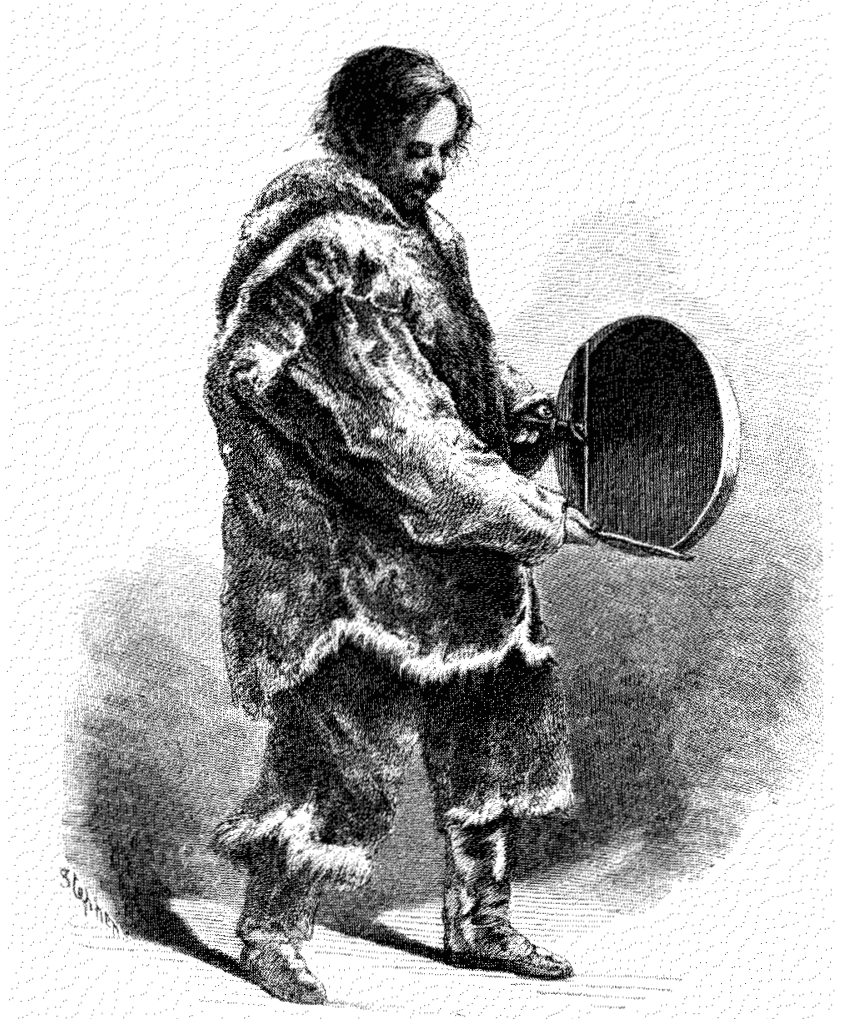

FIG. 3. "Keeloun" or tambourine-type drum, here illustrated from the eastern Arctic (Frobisher Bay area; Hall, 1864, Vol. 2: 198), was typical of Inuit whaling throughout the Arctic. In the east, it was made of deerskin or the skin of a whale's liver (Hall, 1864), stretched over a whalebone hoop; in the west, it was made from the skin of the bowhead's liver, or it could also be made of split seal or walrus bladder, with a spruce frame (Oswalt, 1967: 230).

ment now compete with hunting and gathering for the time and energy of the people during all seasons.

No recent review of the material culture of the North Alaskan Eskimos has been made. It is difficult, therefore, to compare its present status with that described by Murdoch (1892), Spencer (1959) and others. Given the changing nature of modern Eskimo life, we are uncertain about the existence today of an identifiable whale cult such as that described by Lantis (1938) at many of the settlements.

One of us (E.D.M.) was told, while observing the whale hunt at Point Hope in 1967 , that there was one artifact in the material culture related to the whale cult of the local Tikerarmiut that could be supplied only by the bowhead whale. This was a ceremonial drum head, or tambourine skin, fashioned from the membrane encasing the whale's liver (Fig. 3). The Point Hope people are known to have used the "skin" of the bowhead's liver and lungs for drum heads (Rainey, 1947:261; and see photographs in Gruening, 1942, and Evans and Underwood, 1978), but we do not know whether alternative substances could as easily have 
been used (e.g. would the gray whale's liver and lung "skins" serve the same function?). At Point Barrow the drum head traditionally was "a sheet of the peritoneum of a seal," which could be patched as necessary using "pieces of the crop of the ptarmigan" (Murdoch, 1892:385-388). Split seal or walrus bladders were used for making these tambourine-type drums in some parts of Alaska (Oswalt, 1967:230). In the Eastern Arctic the whale's liver "skin" or deerskin was used (Hall, 1864). Certainly the need for a membranous drum head, or any other material artifact for that matter, has not been made a major issue by the Eskimos in their resistance to regulation of the whale hunt. We assume, then, that either acceptable substitutes are available or that parts of the bowhead are no longer used in the manufacture of ceremonial items.

While many of the whaling songs, taboos, and ceremonial observances have been lost over the years, the whaling tradition is still perceived by the Eskimos as an essential connection with their past and as a meaningful elaboration of their distinctiveness as a race. The Cultural Panel at the 1979 Seattle meeting (Anon., $1979 \mathrm{c})$ summarized its view of the importance of whaling today, as follows:

"The complex of whaling and associated activities is perhaps the most important single element in the culture and society of north Alaskan whale hunting communities. It provides a focus for the ordering of social integration, political leadership, ceremonial activity, traditional education, personality values, and Eskimo identity.",

The late mayor of the North Slope Borough, Eben Hopson, (Anon., 1978-79), put it more simply:

"[The whale] is the center of our life and culture. We are the People of the

Whale. The taking and sharing of the whale is our Eucharist and Passover.

The whaling festival is our Easter and Christmas, the Arctic celebration of the mysteries of life."

A significant aspect of the Alaskan whale cult is its affinity to the whale cults found in other parts of the Northern Hemisphere. In her definitive study of this question, Lantis (1938) concluded that "elements of the whaling ritual so overlap each other in distribution that they are like a chain connecting the whaling tribes in the whole area from Kamchatka to Hudson Bay (perhaps some day we can say with certainty: from Japan to Greenland) and from Point Barrow to the coast of Washington." We hasten to point out that in portions of this broad arc of cultural hegemony, bowheads have probably never been present. In other words, whaling traditions (cults, if you will) very similar to those of northern Alaska have been developed and maintained, though with other target species, such as gray and right whales (Heizer, 1968; Mitchell, 1979).

\section{THE MEANING OF SUBSISTENCE}

Subsistence, according to Webster's Third New International Dictionary of the English Language Unabridged, refers to the "means of subsisting: as $a$ : the irreducible minimum (as of food and shelter) necessary to support life . . . b: a mode of obtaining or a source of the necessities of life . . .c: a source or supply of food." The terms "livelihood" and "living" are given as synonyms in this 
dictionary and many others. However, if such synonymy is accepted, then all whalers would be "subsistence" whalers, for whaling is their livelihood, their means of support. Clearly, if the term "subsistence" is to be of any use in debating the Bowhead Problem, a much more narrow definition is required. The 1904 edition of The Century Dictionary and Cyclopedia defines a subsistence diet as "the lowest amount of food on which life can be supported in health." All the dictionaries we have consulted refer, at least by implication, to a quality of sparseness which is connoted by the term subsistence. In common usage, a subsistence life is taken to mean one in which the individual is closely attuned to the bare means of survival.

In sharpening our own understanding of subsistence, we have found a discussion by two authoritative ethnographers to be especially helpful (Driver and Massey, 1957:175). They took subsistence to mean the direct acquisition of food. We recognize (after Driver and Massey) five modes of subsistence living: hunting game, fishing, gathering wild plant foods, farming, and milking or slaughtering domesticated animals. By inference, we propose that hunting for cash with which to buy food and other articles is not subsistence. The trapping of foxes for pelts and the hunting of walruses for ivory, for example, are outside our definition, as the principal products are cash commodities whose value depends directly on a commercial marketing system. By our definition, the Alaskan bowhead fishery is primarily a subsistence endeavor, although the commercial utilization of the baleen and bone make it partially outside the definition (see Table 2). The modern Inupiat culture has been described as "an admixture of both a subsistence and cash economy" (Worl, 1978). We agree with this characterization.

Given that the Alaskan bowhead hunt is mainly a subsistence fishery, to what degree does it fulfill the nutritional requirements of the Alaskan Eskimos? In 1977, when the Bowhead Problem was posed, there was little understanding of the bowhead's nutritional importance. In the environmental impact statement prepared by the U.S. government (Anon., 1977b), the fear was expressed that "the shift from dependence on whale products to the cash economy food stuffs which are available to the villages may lower the nutritional value of the total food consumed." Even more graphic were statements like the following: "According to dietary standards and from a nutritional point of view, the meat, muktuk and oil of the bowhead are vital to the Eskimo diet" (Anon., 1978-79). The implication was that, metabolically, the North Slope Eskimos could not live without whale products, and in particular bowhead whale products.

The findings of the IWC's Nutritional Panel (Anon., 1979c), based on an assessment of available data, did not support such assertions. No "unusual nutritional requirements" could be attributed to Arctic Eskimos. Even a wellrounded diet of "Western-type foods" would be an adequate substitute, nutritionally, for a diet consisting of whale, seal, and other "country foods." However, there is no reason at present for the North Slope Eskimos to reduce their reliance on "country foods," as various forms of wildlife are still locally abundant. No special nutrients found in bowhead meat or muktuk could be identified that are not also found in the tissues of readily available alternative species like 
seals and white whales. Lest there be any doubt, the Panel stated explicitly that "any risk to survival of the bowhead whale which may be posed by the continuance of aboriginal whaling cannot be justified on nutritional grounds."

The Cultural Panel (Anon., 1979c) pointed out that: "To the social scientist, 'wants' are quite different from 'needs.' "' In their view, local needs for certain items, like bowhead whales, cannot be equated with the need for vitamins, energy, or protein. Taste (wants), it is true, may be part of the essence of "culture." When it comes to our conditioned preferences for certain kinds of food, some of us will be reluctant to abandon them even when faced with starvation (Driver and Massey, 1957:175). In a world of plenty, there would be no argument for abridging the right of Eskimos to eat what they will. However, we do not accept the proposition that a people's preference for a particular way of hunting or taste for a given type of food should allow them to exterminate another species.

We would add a further proviso to our working definition of subsistence. No resource base is inexhaustible. Once modern medicine and modern hunting devices are introduced to a subsistence culture, the possibility of resource over-exploitation, with no resultant control of the human population (e.g. starvation and privation), arises. Human communities can live off the land only so long as their own numbers are kept in check; there is a feedback cycle that must come into play with sufficient force to prevent irreversible damage to the resource base. Alternatively, a management regime, with quotas, seasonal closures, gear restrictions, and other effort limitations, can be instituted to ensure rational and sustained exploitation for subsistence purposes.

\section{BIOLOGICAL CONSIDERATIONS}

Much of our concern for the biological survival of the Bering Sea bowhead stock stems from what we know about the condition of other stocks of right whales (Balaenidae). This broader perspective is not generally appreciated by Eskimos and their partisans, who at times seem baffled by the scientific community's solicitousness for what to them appears to be a large population of whales (Anon., 1972; G. C. Ray, quoted in Morgan, 1973; Silook, 1978), or one definitely on the increase (Bockstoce, 1976b; Marquette, 1977; Evans and Underwood, 1978).

Although black right whales (Eubalaena glacialis) were for centuries the mainstay of coastal whaling in temperate regions and an important target of high-seas whalers, they now exist in only portions of their once wide range, and even there as but small, remnant stocks (G. M. Allen, 1942 [1972]; K. R. Allen, 1974:357). Despite nearly complete protection since the 1930's, there is little consistent evidence of recovery, particularly in the Northern Hemisphere.

The Bering Sea bowhead stock, much reduced as it may be, is the only one of four or five separate populations that persists in what can be considered viable numbers. The Spitsbergen stock east of Greenland, once probably the largest, is all but extinct (Reeves, in press). The populations in Davis Strait, Baffin Bay, 
Hudson Bay, and Foxe Basin may be 5-15\% of what they were in the early 18th century (Mitchell and Reeves, in press b). Finally, an isolated population in the Sea of Okhotsk now consists of only a few whales, compared to at least 6500 in the early 1800's (Mitchell, 1977; Anon., 1978).

There is nothing to be gained in attempting to assign blame to particular nations or ethnic groups for the now marginal status of this once widespread family of whales. It seems to have been common for all maritime peoples to hunt whales on whatever scale their level of technology would allow. Unfortunately the right whale family was poorly equipped to resist the efforts of even the most primitive hunters. Right whales (including bowheads) occur close to shore, swim slowly, are comparatively easy to kill, and conveniently float when dead. These attributes, along with their high yield of blubber and whalebone (baleen), made them the "right" whales for hunting, thus the English common name of the group.

While right whales are individually valuable and relatively easy to harvest, they have not shown a high degree of biological resilience. In retrospect, it might be said that they were not the right, but the wrong whales to hunt! We know next to nothing about right whale population dynamics: age at maturation, ovulation rate, length of gestation and lactation, interbirth or calving interval, and longevity. What evidence there is (Donnelly, 1969; Payne, 1976; W. A. Watkins, pers. comm. 1979) suggests that they are slow to reach maturity and that females probably do not give birth more often than at a maximum once every two or three years. Natural mortality factors are unknown, but killer whales are known predators, and bowheads are known to die from ice entrapment (Mitchell and Reeves, in press a).

The view expressed by the IWC Scientific Committee in 1977 - that there should be a complete moratorium on bowhead whaling - was based on a consideration of the risk of extinction (Anon., 1978). Natural disasters alone, such as ice entrapment or inability to reach preferred feeding grounds due to extreme ice conditions, could extirpate an already depleted population (Vibe, 1967). Any hunting mortality, then, increases the risk that some critical population size, at which decline to extinction due to natural mortality factors alone is irreversible, will be reached (Allen, 1974). Not far from the Committee's minds was "the potential pollution hazard associated with petroleum development in the North American Arctic and its possible critical consequences for stocks at low levels of abundance"' (Anon., 1978). Given the instability of the bowhead's biotope, the small fraction of initial population size represented by existing stocks, and the growing threat of environmental degradation, the Committee had no choice but to recommend a quota of zero. Mathematical analyses demonstrating that a "zero quota" is the only safe course were recently presented by Breiwick et al. (in press).

Whatever the risks, whaling has continued and is unlikely to stop, advice from scientists notwithstanding. The impact of continued hunting will be measured not only by the number of whales killed or wounded, but also by the age and sex of the animals removed from the population. Judging from accounts by Cook 
(1926) and Bodfish (1936), it appears that Yankee commercial whalers in the 1890 's and early 1900's responded to the high market value of baleen by selecting for large whales and overlooking smaller ones whose baleen would give a comparatively poor return. Such a practice would have left a whale population skewed in favour of young animals when the commercial fishery ended about 1910-1920. Available information (Maher and Wilimovsky, 1963; Marquette, $1976 ; 1978 ; 1979)$ suggests that, although Eskimos have taken whales of all sizes and both sexes, the majority of the whales they land are immature.

It is not clear whether the landed catch represents present population structure. If it does, then the population is abnormally structured, because well over half of the whales landed since 1973 have been immature (Marquette, 1977; 1978; 1979). Alternatively, there could be a bias (i.e. selection) in the fishery, which would mean that the landed catch is not representative of present population structure. Another possibility is that the hunt is not selective, but that the smaller whales are landed more frequently. In this case, the kill might be representative of the population, but the landed catch would not be. Any analysis of population trends must take into account the possibility that the structure of the bowhead population was substantially changed during the commercial fishery. Continued selection of some type might have reinforced this abnormal structure. The possibility of recruitment failure and population crash, with or without hunting, cannot be completely ruled out (Anon., 1980a: para. 12.1).

In view of the Technical Committee Working Group's recommendation concerning gray whale substitution, we consider here the biological appropriateness of shifting whaling effort toward this species. Fortuitously, the IWC Scientific Committee has completed a recent review of the eastern Pacific stock's status (Anon., 1979d, and associated documents). A catch limit of 178 gray whales per annum has been suggested for the Soviet fishery (Anon., 1979b). Ohsumi (1976) estimated a potential maximum sustainable yield of 250 gray whales if the population originally numbered 14900 . Recent estimates of present population size are close to 15000 (Rugh and Braham, 1979). It would, therefore, seem reasonable to assume that an allocation of 50 or more gray whales to Alaskan Eskimos could be made without putting that whale population at appreciably greater risk. Problems of availability and cultural acceptability are considered in another section (see below).

A peculiarity of the Bering Sea bowhead population is that its spring migration path follows a narrow shore lead along the North Alaskan coast (Braham et al., in press). This means that, in some years at least, virtually the entire population passes within sight of one or more whaling villages, making it locally abundant. This phenomenon leads to the perception on the part of the Eskimos that bowheads are plentiful. In fact, they are now regionally scarce. Gray whales, by contrast, do not pass through Bering Strait until much of the ice has cleared from the southeastern Chukchi Sea (Rice and Wolman, 1971), and they forage in summer across a broad expanse of both the Bering and Chukchi Seas. Consequently, the Eskimo's perception of the gray whale may be that it is scarce in northern waters, which it is locally. Regionally, howev- 


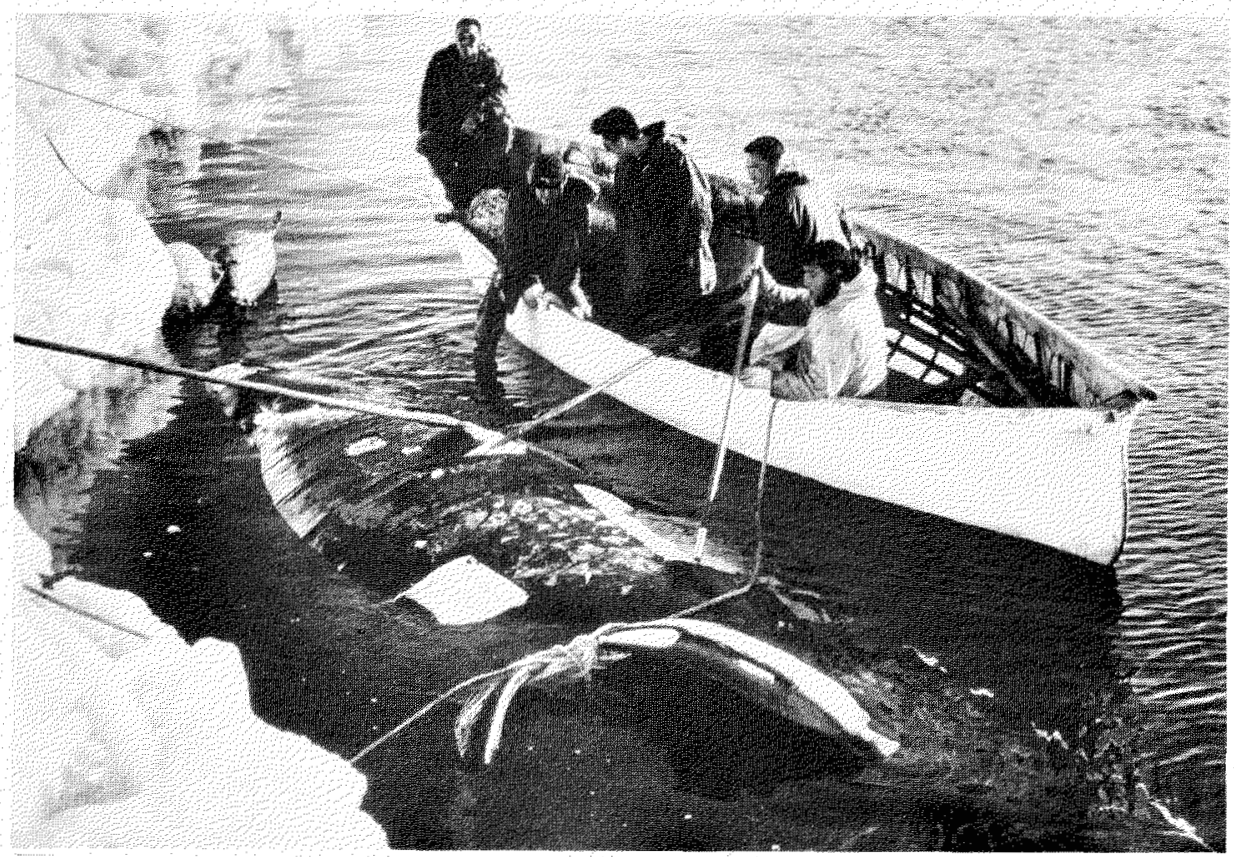

FIG. 4. Bowhead caught off St. Lawrence Island, May 1, 1961, showing the method of tying the flippers together to facilitate towing to the ice edge. (Photo from G.C. Pike collection)

er, the gray whale is abundant and widely distributed in the eastern North Pacific and Arctic oceans.

\section{WHALING TECHNOLOGY}

There are several ways to evaluate present-day Eskimo whaling technology. First, is it consistent with traditional values, i.e., supportive of the early aboriginal culture which, everyone seems to ágree, should be maintained? Second, how does it affect the scope of the hunt and the rate at which the bowhead population is being taxed? A third consideration is the adequacy of present whaling technology for harvesting gray whales.

\section{Traditional}

The pre-contact Eskimo relied on two weapons for attacking bowhead whales: the harpoon and the lance (Heizer, 1968; Sonnenfeld, 1960). Floats attached to the harpoon by a rawhide line enabled the hunter to follow the movements of a struck whale (Fig. 4). They also helped to exhaust the animal and to make it more approachable. At Point Hope three floats - one large and two small - generally were fastened to each harpoon line (Rainey, 1947) and the use of multiple pokes was common (Stefánsson, 1914:390: Spencer, 1959:342; D. C. Foote cited by Durham, 1974). The lance was used to sever the tendons controlling the tail flukes and to administer the coup de grâce by penetration of vital organs (Van Valin, 1945). 
The umiak, usually driven by paddles, was the primary means of transportation (Collins, 1892). Barrow Eskimos apparently once used caribou hide (and later canvas) sails (Durham, 1974), and the people of St. Lawrence Island, who use sails today (Slwooko, 1977), probably had a similar tradition. The organization of whaling crews, the sharing of whale products, and the myriad of customs observed before, during, and after the hunt were all part of the whaling tradition (Lantis, 1938; Rainey, 1947; Spencer, 1959).

\section{Modern}

Firearms were introduced to Eskimos in the Bering Strait region in the early 1800's (Ray, 1975), but it was not until the arrival of American whalemen during the late 1800's that explosives were incorporated into Eskimo whaling technology (Murdoch, 1892; Sonnenfeld, 1960). The darting gun (sometimes referred to as the bomb lance) was specially developed for whaling in the Arctic, and it quickly replaced the conventional Eskimo harpoon. The beauty of the darting gun is that it allows the simultaneous attachment of a harpoon-line-float array to the whale and the discharge of an explosive missile (or bomb) into the animal's flesh. The conventional lance was largely replaced by the shoulder gun, which also fires a bomb at the whale. These two implements have become the principal weapons used by the Eskimos in Alaska for killing bowhead whales (Bailey and Hendee, 1926; Rainey, 1941; Marquette, 1976). Gray whales and belugas are killed with rifles (Murdoch, 1892; Maher, 1960; Marquette, 1976).

The umiak is still the main vessel used for stalking bowhead whales in the spring ice-lead hunt (Marquette, 1976). Sails are used regularly at St. Lawrence Island (Slwooko, 1977), but elsewhere paddles are used exclusively (Murdoch, 1892). During the fall open-water hunt, wood or aluminum boats, driven by large outboard or inboard motors, are used (Maher and Wilimovsky, 1963; Nakashima, 1977; Marquette, 1978). Block-and-tackle are used for hauling dead whales onto the ice in spring (Marquette, 1976), and trucks and tractors are used sometimes for dragging them onto the beach in fall (Nakashima, 1977; Durham, 1979; our Fig. 5). Modern Eskimo whalers communicate with one another by radio (Nakashima, 1977; Worl, 1978). One of us (R.R.R.) was present at Kaktovik in September 1978 when a single-engine aircraft chartered by a whaling captain was used to scout for whales; we do not know the extent to which aircraft are used for reconnaissance by the whalers.

There are few published sources that compare the present-day hunt to earlier hunts on the basis of crew composition and hierarchy, principles of sharing in the products, and the various songs, taboos, and rituals that once characterized the whale cult. Many of these characteristics have been modified or lost (Spencer, 1959; Marquette, 1976; 1978; 1979). However, there is reason to believe that much of the integrity or spirit of the hunt, as conducted in pre-contact times, remains, particularly at Point Hope (Rainey, 1947; Marquette, 1976; 1978; 1979).

\section{Evaluation}

The extent to which present-day bowhead whaling honors the whaling heritage of the Inupiat is an open question. There have been dramatic changes in technology over the years. Much of the privation and risk that attended the hunt 


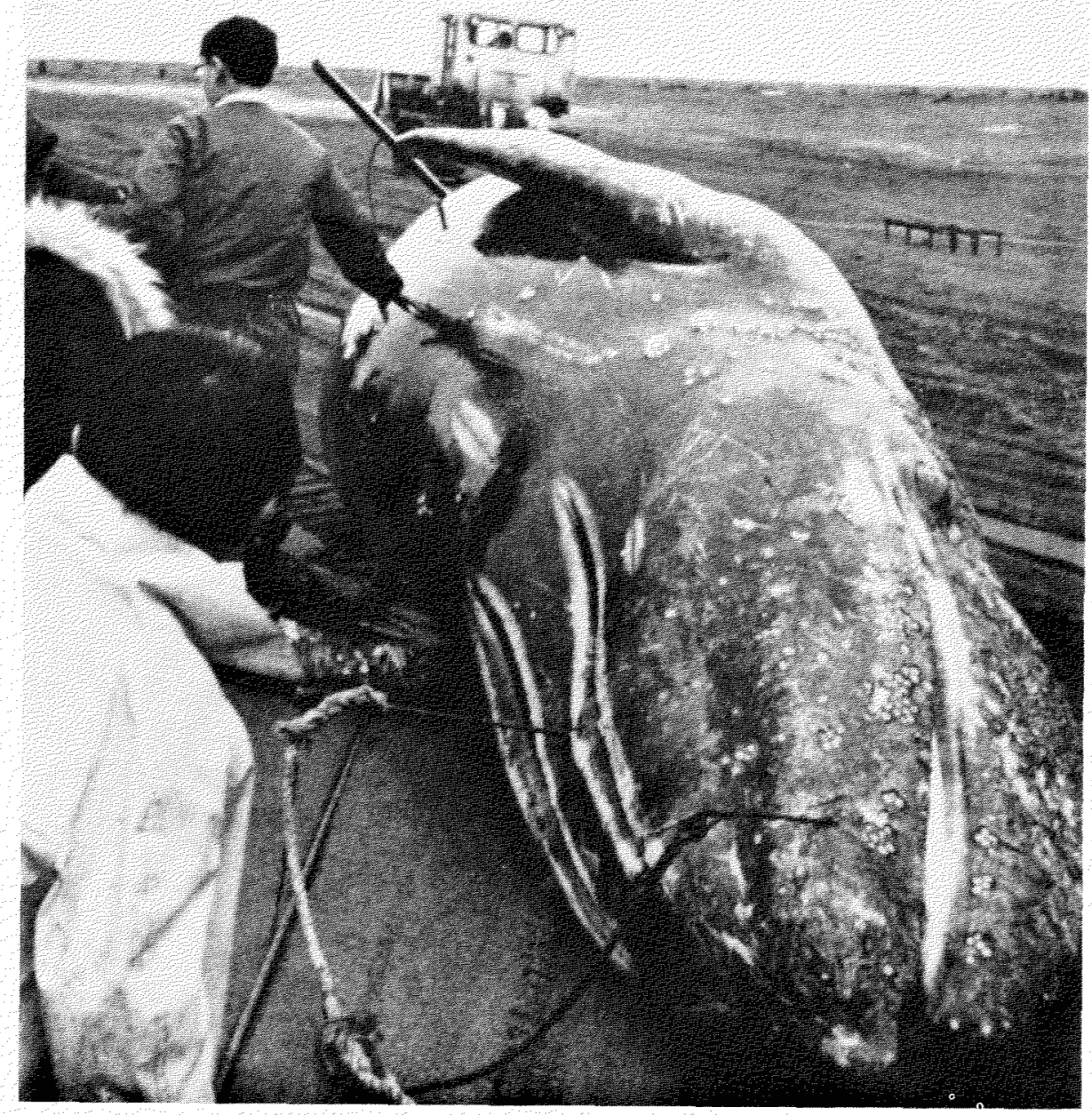

FIG. 5. Gray whale killed near Barrow Village, September 11, 1958 (Photo by S. Nathanson, from Maher, 1960: Fig. 2). During the fall season, tractors, like the one in the background, are often used for dragging a killed whale onto the beach. The circular white scars on the whale's skin are barnacles or their attachment sites, cited by some as a reason for the unsuitability of gray whale muktuk as a substitute for bowhead muktuk. The people of St. Lawrence Island relish the meat of the gray whale (Marquette, 1979).

in earlier times has been reduced by store-bought goods and modern communication and transportation devices. Today's whaling captains invest at least $\$ 9000$ in gear and spend $\$ 2000$ to feed and maintain a crew (Bocktstoce, 1977). In spite of this high cost, whaling effort steadily increased during the 1970's, due in large part to the cash made available by "petroleum exploration employment and settlement of compensation claims relating to land rights" (Anon., 1978). "While the aboriginal system was independent of the market economy, the contemporary whaling system is dependent on an access to cash income to purchase technological equipment manufactured in the capital [ist] system" 
(Worl, 1978). Still, it is difficult to measure the degree to which these "Western embellishments" (Sonnenfeld, 1960) have eroded the conservative nonmaterial culture of the Eskimos.

As for the consequences of changed technology to the whale population, we can speculate with more assurance. The problem of excessively high struck-butlost rates, which we judge to be crucial, is not new. Misuse of the shoulder gun apparently has occurred ever since the device was introduced (Sonnenfeld, 1960; Durham, 1974). There is little doubt that failure to fasten to whales (with the darting gun) before shooting (with the shoulder gun) is a major cause of struck whales being lost (Fiscus and Marquette, 1975). Whalers are known to stand on the ice and fire the shoulder gun (Murdoch, 1892; Bailey and Hendee, 1926; Rainey, 1942; Morgan, 1974), a practice that ensures a high struck-but-lost rate. According to Nelson (1969:219), in all North Slope villages except Point Hope, "whales are first shot with a 'bomb' from a shoulder gun."

Another major reason for the escape of a high proportion of struck whales is malfunctioning of the darting gun (Fiscus and Marquette, 1975). The fuse and the keeper are the weak points of the bomb. Whales frequently escape when the implanted bomb fails to explode. Misfires can occur when the keeper fails to break, the fuse does not ignite, or the powder is wet. The bombs for both the shoulder gun and the darting gun are provided through the Alaska Native Industries Co-op Association. They are manufactured by the Naval Gun Company, Doylestown, Pennsylvania, using a design basically unchanged since the introduction of the bombs to the arctic fishery during the late 1800's (Fiscus and Marquette, 1975). In October 1977 the manufacturer met with Eskimo whalers, and subsequently some modifications in the design of the guns and bombs were made (Braham et al., 1979).

The use of machines in the modern aboriginal whale fishery increases its potential impact on the whale stock. Snowmobiles make travel to and from the ice camps faster and more regular during the spring hunt and may allow more hunters to spend more time hunting whales than in pre-snowmobile days (although the relative efficiency of snowmobiles and dogteams may vary according to circumstances). Certainly the use of motorboats has widened the scope of fall whaling at Barrow and Kaktovik (Durham, 1979).

\section{SUBSTITUTIONS/ALTERNATIVES}

The idea of substituting one source of food for another is not alien to Eskimo culture. It is in fact the willingness to make such tradeoffs that has made the culture so resilient. The Cultural Panel (Anon., 1979c) referred to "the adoption of ecological strategies that allow the population to exercise considerable flexibility in meeting their needs," deciding "which resources to use and employing a wide range of techniques."

Nelson (1969:6) referred to the ability of the Wainwright Eskimos "to turn from one resource to another when it is necessary to do so." In years when no bowheads were taken at the whaling villages, "hunting efforts shifted to another species, mainly walrus at St. Lawrence Island and caribou farther north" (Evans and Underwood, 1978). It has been suggested that the increased harvest of 
bowheads during the 1970's was a predictable, adaptive response on the part of the Eskimos to their own population increase and the decline in availability of caribou (Anon., 1978; Peterson, 1978).

In assessing resource alternatives, it is necessary to consider each whaling village separately. "There are great differences among the [whaling] communities in their dependence on the bowhead" (Peterson, 1978). For instance, at St. Lawrence Island there are two whaling villages, Savoonga and Gambell, which share their whale catch equally (Marquette, 1979). Walruses and seals are, by far, the preferred and most readily available sources of meat at these settlements (Peterson, 1978). Rice and Wolman (1971) noted: "The natives of the village of Gambell on St. Lawrence Island (Francis H. Fay, personal communication) and the villages of Sireniki, Imtuk, Chaplino, Naukan, Uelen, and Enurmino on the Chukotskiy Peninsula (Tomilin, 1957; Treschev, 1966a) also still hunt whales. The catch in these areas is almost entirely gray whales." Most discussions of "gray whale substitution," including the Wildlife Panel report (Anon., 1979c), have ignored the fact that gray whales are readily available to St. Lawrence Island Eskimos, and that these people have a history of hunting them. A gray whale taken at St. Lawrence Island in May 1977 prompted Marquette (1979) to remark that although the muktuk of this species is "thinner and less desirable" than that of the bowhead, its meat "is highly prized as food."

At North Slope whaling villages, caribou is the primary source of meat, and at several of them fish is substantially more important than bowhead whale as a source of meat (Peterson, 1978).

One early author (Murdoch, 1898), basing his comments on observations made at Point Barrow during the 1880's, was relatively unimpressed by the importance of whales in Eskimo subsistence. He regarded the ringed seal, Phoca hispida, as "the great staple food" and concluded that an Eskimo community on the North Slope could rely almost exclusively, year-round, on this ubiquitous pinniped. Whales were, in his view, "by no means essential to their [the Eskimos'] existence." The capture of a few whales added to a community's material comfort and made it "far more prosperous than most of the Eskimo communities with which we are familiar."

More recently, Sonnenfeld (1960) indicated that seals, while affording less prestige to their captors than whales, were "more basic to Eskimo subsistence." Johnson et al. (1966), referring to Point Hope, indicated that there is a direct tradeoff between whaling and the hunt for caribou, ringed seals, and bearded seals, and that "the returns are greater for the effort spent on these species [caribou and seals]."' Finally, Nelson (1969:214), who had considerable experience at Wainwright and Point Hope during the mid-1960's, described the bowhead whale resource as "sporadic in comparison to 'everyday' game such as seal, caribou, walrus, and waterfowl."

There is no doubt that the whale hunt is the highest-profile activity of Eskimo hunters in northwest Alaska. Whether it is also critical to their subsistence, taking into account the various potential substitutes listed by the Wildlife Panel, is not clear. A proper quantitative assessment of available substitutes is neces- 
sary. Differences in need and availability between villages must be taken into account, as must the vulnerability of other species to overexploitation that might result from a shift of hunting emphasis.

\section{GRAY WHALE SUBSTITUTION/ALTERNATIVE}

From a biological standpoint, the substitution of gray whales for bowhead whales as targets of Eskimo whalers is desirable. We believe that gray whales on their summer feeding grounds can be harvested and processed with little change in Eskimo whaling technology. But can an increased gray whale catch become a palatable, culturally acceptable substitute for part, or all, of the bowhead catch? Only the Eskimos themselves can answer this question.

The dangers associated with the capture of gray whales have been greatly exaggerated, although there certainly are differences in the ease with which different species of whales can be captured. The Nootka of the Northwest Coast hunted humpback, right, and killer whales (Drucker, 1951), but they preferred "those small [whales] with hunches on their backs [meaning gray whales], as being the most easy to kill" (Meares, 1791 [1967]:240). The famous American whaling captain Charles Scammon (1874) related his experiences with gray whales in their enclosed breeding lagoons in Baja California. There, the confined situation and the presence of calves undoubtedly contributed to the risks associated with their capture. Scammon (1869) acknowledged a great difference between lagoon and open-coast whaling for gray whales. He wrote: "The casualties from coast and kelp-whaling are nothing to be compared with the accidents that have been experienced by those engaged in taking the females in the lagoons." Scammon (1869) and many others (cited by Heizer, 1968, and Mitchell, 1979) noted that Indians along the coast of the Pacific Northwest and Eskimos in the Arctic have, for centuries, used primitive methods to capture gray whales (e.g. see our Fig. 6).

Given the reputation of gray whales as "devilfish," the status earned by the whaler for effecting their capture should be equivalent to or greater than that earned by capturing bowhead whales. Among the Northwest Coast Indians, the man who killed a gray whale acquired "the greatest reputation" among his fellows, with "the most exalted mark of honor conferred upon [him] by a cut across the nose" (Scammon, 1874; also see Colson, 1953:208; Curtis, 1916 [1970]). There is a long history of exploitation of gray whales by native people living along the coasts of the North Pacific Ocean and Bering Sea (Mitchell, 1979; our Fig. 7), and it extends to most of the whaling villages of northwest Alaska, including Gambell on St. Lawrence Island (Rice and Wolman, 1971), Wainwright (Maher, 1960), and Barrow (Maher, 1960; see our Fig. 5). One gray whale was killed in 1933 at Cross Island, which is nearer to Kaktovik, the easternmost Alaskan whaling village, than to Barrow (Maher, 1960). This tradition has been maintained, as evidenced by the 21 gray whales reportedly taken by Alaskan Eskimos between 1970 and 1977 (Wolman and Rice, 1979).

Catch records given by Maher (1960) and Maher and Wilimovsky (1963) suggest that gray whales have been taken at Barrow in years when the spring 


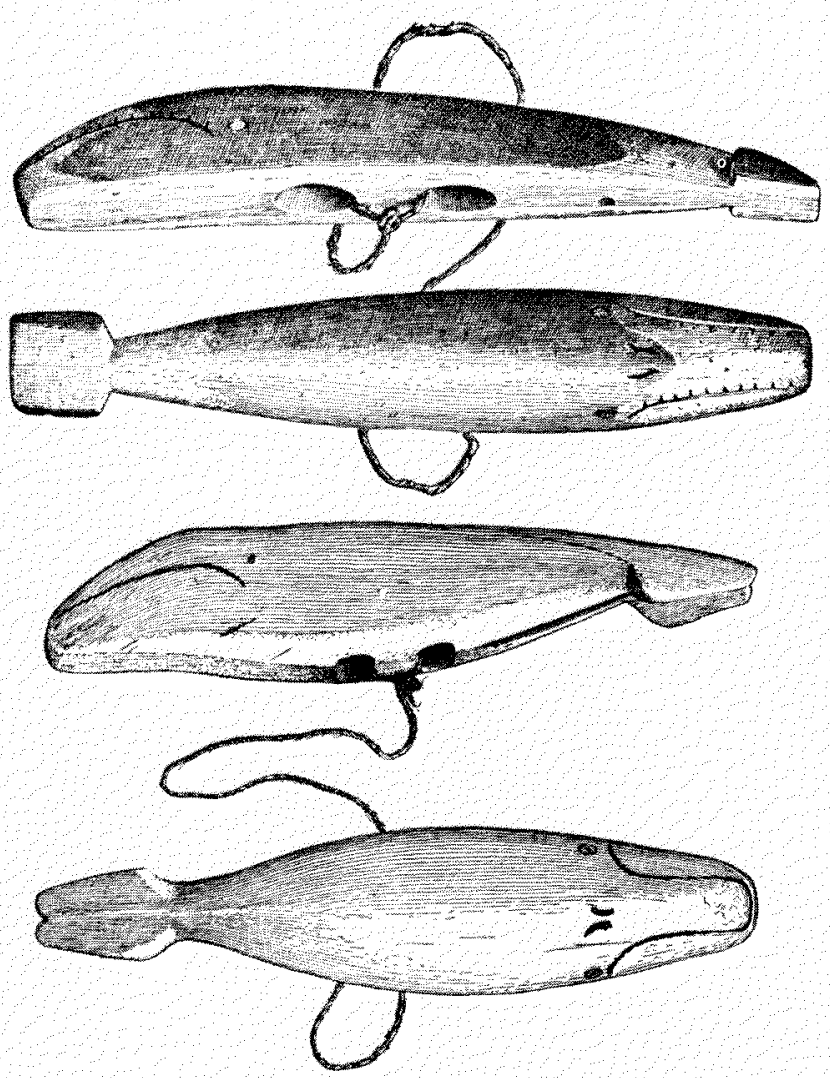

FIG. 6. Ivory whales about 5 inches long, made from walrus tusks, with holes for the attachment of thongs. These toggles were used to tie the whale's flippers together across its belly (c.f. our Figure 4), a method of reducing drag as the carcass was towed tail-first to the ice edge. Murdoch (1892, original Fig. 250) considered the top one a bowhead whale, the bottom one a gray whale. We agree with Murdoch's judgment and have noted similar use of both bowhead and gray whale images in ivory carvings associated with the whale cult of Alaska on display at the Los Angeles County Museum of Natural History. These artifacts suggest that the gray whale figured at least to some degree in the cultural life of early Eskimos in Alaska.

hunt for bowheads has been a failure. Unfortunately, we do not know whether or not the feasts and ceremonies associated with the whale hunt were held in these years (1954, one neonatal bowhead taken, one juvenile gray; 1958, no bowheads, two medium-sized grays; 1959 , no bowheads, six grays of various sizes). We can be sure that the "whale cult" was not entirely "lost", however, despite a three-year period (1957-59) when no bowheads were taken at Barrow. Circumstantially at least, it appears as though an unusually large catch of gray whales (eight) helped the Barrowacommunity weather this lean period. Of course, as the Cultural Panel pointed out, there is an important difference, culturally if not nutritionally, between carrying out an unsuccessful hunt and having no hunt at all. 

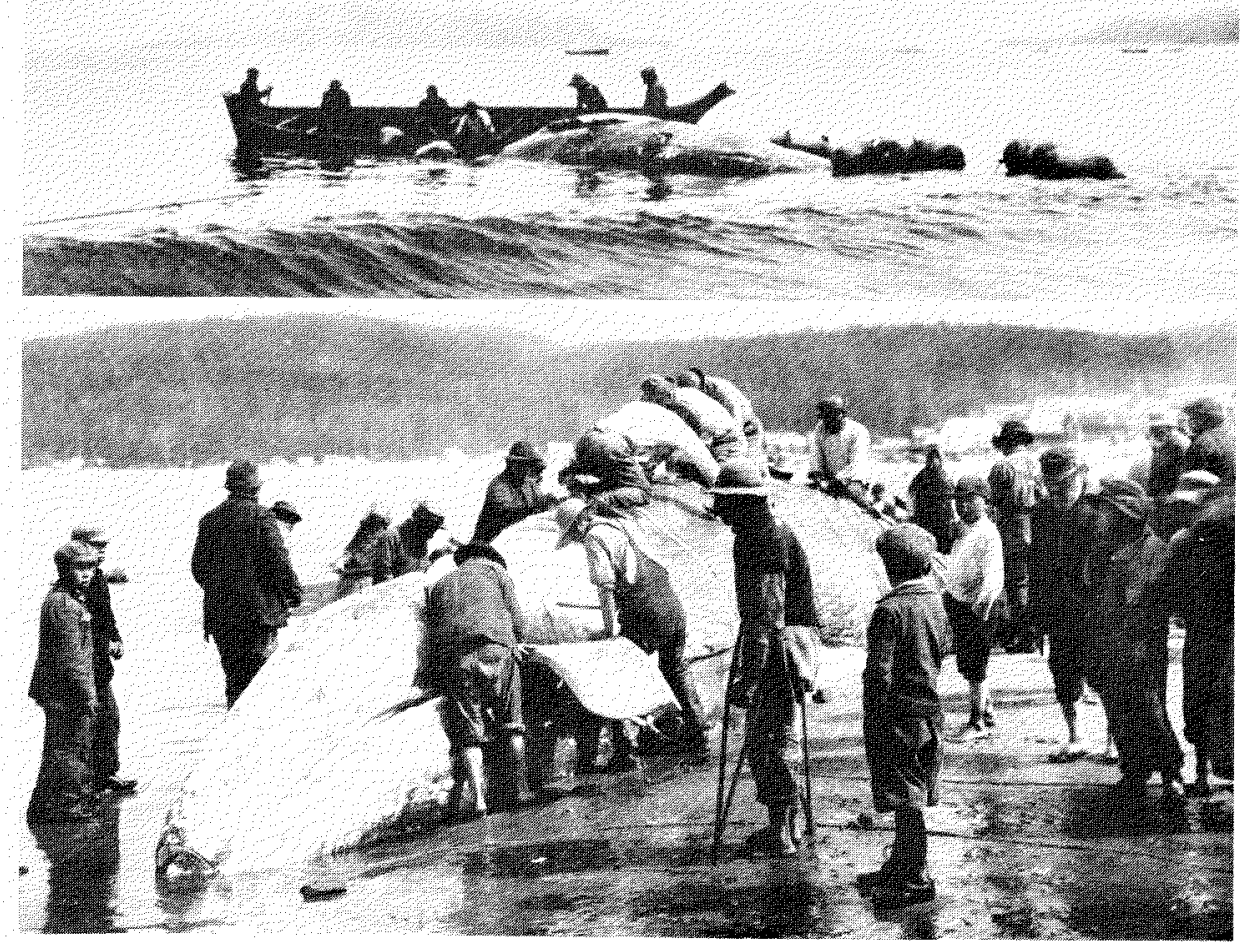

FIG. 7. The capture of gray whales by Makah Indians at Neah Bay, Washington, was typical of the oar-driven, open-boat hunt employing the harpoon-line-multiple float technology common to the Northwest Coast Indian, Alaskan Eskimo, and Siberian Chukchee civilizations (Heizer, 1938). At least after the mid-19th century and possibly long before, the gray whale was an important element, nutritionally and culturally, in the lives of the Northwest Coast Indians (Mitchell, 1979). (Photos by Asahel Curtis, 1922, top; 1910, bottom. Courtesy of University of Washington, Northwest Coast Collection).

The arguments for and against "gray whale substitution" have been reviewed in a working paper widely circulated by an American conservation group and tabled by the U.S. IWC delegation in 1980 (Storro-Patterson, 1980a). We expect the issue to foment much controversy in the IWC, the U.S. government, and North Slope communities.

\section{Evaluation/Opinion}

A desirable management solution to the political Bowhead Problem would involve the following set of compromises. Any continued hunting of bowheads probably will be justified on the basis of nutritional and cultural "needs." We believe the nutritional needs in question can be met within the existing pattern of resource utilization, involving an increase in the take of alternative species that are locally and seasonally abundant. This would include the gray whale, at least where it is seasonally available to whaling villages, as it is on a consistent basis south of Point Hope. The cultural needs in question are less easily met by the simple redirection of hunting effort toward a species other than the bowhead. 


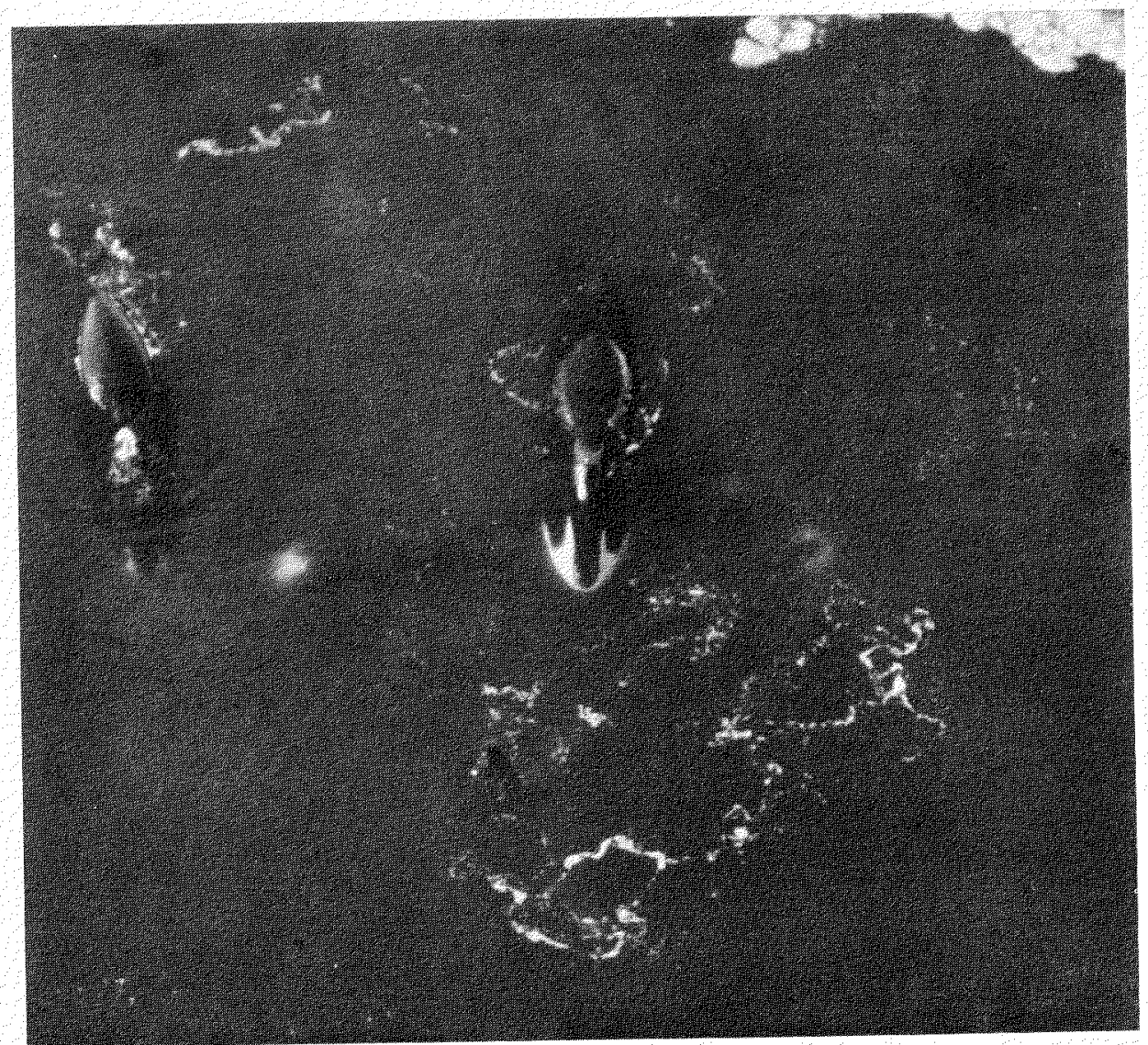

FIG. 8. Aerial photograph of 4 bowhead whales north of Bering Strait, April 24, 1978. (Photo by Stephen Leatherwood)

However, we believe that an increased take of gray whales and a limited take of bowheads can, in combination, satisfy most, and possibly all, of the cultural needs of the whaling villages. The preparation for and carrying out of the gray whale hunt should help preserve the whaling culture in which the very act of communal hunting is considered an important part of the social fabric. If the gray whale hunt fails to satisfy certain specific cultural requirements, then the taking of a bowhead might be justified. As the whale cult survived for centuries despite periods with few or no kills at certain villages, a single killed bowhead must be sufficient for observing the whaling ceremonies and rituals of a given village.

\section{CONCLUSIONS}

We conclude that:

(1) The Alaskan Eskimo hunt for bowhead whales (Fig. 8) is an example of modern aboriginal whaling, conducted locally, mainly for subsistence but partially commercial, employing transitional and mechanical techniques. It is one of several existing fisheries that are other than strictly commercial and may 
deserve special status under the International Convention for the Regulation of Whaling and relevant domestic laws.

(2) On biological grounds there is an urgent need for a reduction of the kill of bowhead whales in the Bering Sea stock. The only defensible management regime based on biological evidence is complete protection.

(3) The best argument for any continued bowhead whaling is that it is essential to the non-nutritional cultural well-being of Alaskan Eskimos. However, under no circumstances should the cultural survival of a human community be placed ahead of the biological survival of a species.

(4) If for political reasons the hunt cannot be suspended, a compromise involving some increase in the exploitation of species other than the bowhead whale and a corresponding decrease in the take of bowheads is desirable and feasible. In particular, the gray whale has proven to be a suitable alternative species. While the substitution, whale for whale, of gray whales for bowhead whales would require some adjustments in the seasonal activity cycle and the consumption patterns of the Eskimos, the ultimate cultural and nutritional consequences would be positive. Only as the bowhead's survival is secured can the future of an Eskimo bowhead whaling culture be assured.

(5) Assuming that alternative food resources, and even an alternative large whale species, are available to meet all the nutritional and at least some of the cultural demands of the Eskimos, any bowhead take should be kept as low as possible. It should be based on documented cultural needs of individual communities having a long and continuous history of bowhead whaling.

Available evidence suggests that Point Hope, the oldest extant whaling village in northern Alaska and the one least affected by Western influences, may have a strong cultural case for a small bowhead quota; Wainwright may as well. Barrow, the largest and most Westernized of the important whaling villages, has sustained periods of little or no bowhead whaling success in the recent past and has better opportunities to take gray whales. The villages on St. Lawrence Island have a history of reliance on a subsistence base of walrus, seal, and gray whale, the bowhead having little documented significance to their economy. Villages that have been established recently or that take bowheads only sporadically do not have a strong argument for continuing or initiating a bowhead hunt at the present time; this includes all Canadian western Arctic villages.

We recommend that more gray whales and fewer bowheads be taken by the Alaskan whaling villages. No more than one bowhead should be taken annually per village, and then only by those villages with a long tradition of bowhead whaling.

(6) While modern whaling techniques appear to have become interwoven with traditional methods, certain time-honored principles of good whaling practice should be re-emphasized. Most importantly, the traditional technique of fastening to the whale with at least one float and preferably an additional small "telltale" at the free end of the harpoon line before attempting to kill it, needs to be made a requirement in order to reduce the unacceptably high struck-but-lost rate. This recommendation has been made repeatedly by others (Fiscus and 
Marquette, 1975; Bockstoce, 1977; and IWC reports since 1976). The Alaska Eskimo Whaling Commission reportedly has promulgated a rule requiring that a harpoon be attached simultaneously with or prior to the use of the shoulder gun (Braham et al., 1979, Appendix), but this needs to be confirmed. The taking of whales in the traditional manner, by fastening with a harpoon, line, and multiple floats, and then killing with a lance, would ensure greater efficiency in the hunt and reinforce the traditional values and activities associated with aboriginal whaling.

(7) Simple changes to improve the efficiency of the darting gun, such as grooving of the bomb to control fragmentation, use of waterproof powder, primers and sealers, and substitution where appropriate of modern materials such as steel and plastic, are desirable. Such modifications would improve the efficiency of the darting gun without changing the "feel" of the implement or affecting the hunting technique. Coupled with the requirement that at least one and preferably multiple floats be fastened to the whale concurrent with or before attempts to kill it, these proposed changes would reduce the struck-but-lost rate and allow more efficient hunting of the gray whale. Some improvements in the hunting implements reportedly have been made in recent years (Braham et al., 1979), but much more attention needs to be given to this aspect of the hunt.

\section{REFERENCES}

ADAMS, J.E. 1971. Historicai geography of whaling in Bequia Island, West Indies. Caribbean Studies 11:55-74.

1975. Primitive whaling in the West Indies. Sea Frontiers 21(5):303-313.

ALLEN, G. M. 1942. Extinct and Vanishing Mammals of the Western Hemisphere with the Marine Species of all the Oceans. American Committee for International Wild Life Protection, Special Publication No. 11. 620 p.

1972. Extinct and Vanishing Mammals of the Western Hemisphere with the Marine Species of all the Oceans. Special Publication No. 11. New York: Cooper Square Publishers, Inc. 620 p.

ALLEN, K.R. 1974. Recruitment to whale stocks. In: Schevill, W. E. (ed.). The Whale Problem. A Status Report, Cambridge, Massachusetts: Harvard University Press. 352-358.

ANONYMOUS. 1972. Ocean Mammal Protection. Hearings before the Subcommittee On Oceans And Atmosphere of the Committee On Commerce, United States Senate, Ninety-Second Congress, Second Session on S.685, 1315, 2579, 2639, 2871, 3112, 3161, and amendment 1048, ocean mammal legislation. Serial No. 92-56. U.S. Government Printing Office, Washington. Part 1, February 15, 16, 23, and March 7, 1972: i-viii + 1-837. Part 2, May 11, 12 and 13, 1972: i-vi + 839-1192.

ANONYMOUS. 1973. Report of the Scientific Committee. London. Report of the International Whaling Commission 23; 28-259.

ANONYMOUS. 1977a. Report of the Scientific Committee. Cambridge. Report of the International Whaling Commission 27:36-68.

ANONYMOUS. 1977b. International Whaling Commission's Deletion of Native Exemption for the Subsistence Harvest of Bowhead Whales. Final Environmental Impact Statement, U.S. Department of Commerce, NOAA, National Marine Fisheries Service, Volume 1: Summary and Text, i-viii + 1-247. Volume 2: Appendix A through I.

ANONYMOUS. 1978. Report of the Scientific Committee. Cambridge. Report of the International Whaling Commission 28:38-92.

ANONYMOUS. 1978-79. The People of the Whale: A Fight for Survival. Indian Affairs, No. 98: 7-8.

ANONYMOUS. 1979a. Soviet Union Progress Report on Cetacean Research June 1977-May 1978. Cambridge. Report of the International Whaling Commission 29:131-134.

ANONYMOUS. 1979b. Chairman's Report of the Thirtieth Annual Meeting. Cambridge. Report of the International Whaling Commission 29:21-37. 
ANONYMOUS. 1979c. Reports and documents from Panel Meeting of Experts on Aboriginal/Subsistence Whaling. Seattle, Washington, February 5-9, 1979. [Including reports of the nutrition and cultural panels, 6 background documents and 7 letters.]

ANONYMOUS. 1979d. Report of the Scientific Committee. Cambridge. Report of the International Whaling Commission 29:38-105.

ANONYMOUS. 1980a. Report of the Scientific Committee. Cambridge. Report of the International Whaling Commission 30:42-137.

BAILEY, A.M. and HENDEE, R.W. 1926. Notes on the mammals of Northwestern Alaska. Journal of Mammalogy 7:9-28 + 3 pls.

BARNES, R.H. 1974. Lamalerap: a whaling village in eastern Indonesia. Indonesia (Cornell University, Ithaca, N.Y.) 17 (April):136-159.

BOCKSTOCE, J.R. 1976a. On the development of whaling in the Western Thule culture. København. Folk 18:41-46.

1976b. Speculations on the increase in bowhead population. Cetacean Times 2(1):8-9.

1977. An issue of survival: bowhead vs. tradition. Audubon 79(5):142-145.

and BOTKIN, D.B. 1980a. The historical status and reduction of the western Arctic bowhead whale (Balaena mysticetus) population by the pelagic whaling industry, 1848-1914. Final Report to the National Marine Fisheries Service by the Old Dartmouth Historical Society (New Bedford Whaling Museum) under Contract 03-78-M02-0212: i-v + 1-160.

BODFISH, H.H. 1936. Chasing the bowhead. Cambridge: Harvard University Press. Frontis $+\mathrm{i}-\mathrm{x}$ $+281 \mathrm{p} .+9$ pls.

BOGORAS, W. 1904-1909. The Chukchee. Memoirs of the American Museum of Natural History 11: i-xvii + 1-733.

BRAHAM, H., FRAKER, M. and KROGMAN, B. In press. Spring migration of the western Arctic population of bowhead whales. Marine Fisheries Review 42.

BRAHAM, H., KROGMAN, B., LEATHERWOOD, S., MARQUETTE, W., RUGH, D., TILLMAN, M., JOHNSON, J., and CARROLL, G. 1979. Preliminary report of the 1978 Spring Bowhead Whale research program results. Cambridge. Report of the International Whaling Commission 29:291-306.

BREIWICK, J.M., MITCHELL, E.D., and CHAPMAN, D.G. In press. Estimated initial population size of the Bering Sea stock of bowhead whale, Balaena mysticetus: an iterative method. Fishery Bulletin 78(4).

CALDWELL, D.K. and CALDWELL, M.C. 1975. Dolphin and small whale fisheries of the Caribbean and West Indies: Occurrence, history, and catch statistics - with special reference to the Lesser Antillean Island of St. Vincent. Journal of the Fisheries Research Board of Canada 32(7):1105-1110.

CAWTHORN, M.W. 1979. New Zealand Progress Report on Cetacean Research June 1977-May 1978. Cambridge. Report of the International Whaling Commission 29:123-125.

CLARKE, R. 1954. Open boat whaling in the Azores. The history and present methods of a relic industry. Cambridge. Discovery Reports 26:281-354 + folding table + pls. 13-18.

1956. Sperm whales of the Azores. Cambridge. Discovery Reports 28:237-298 + pls.1-2.

COLLINS, J.W. 1892. The fishing vessels and boats of the Pacific coast. Washington: U.S. Government Printing Office. Bulletin of the U.S. Fish Commission for 1890. 13-48 + pls. 5-17.

COLSON, E. 1953. The Makah Indians. A study of an Indian tribe in modern American Society. Manchester: The University Press. i-xvi +308 p.

COMPTON-BISHOP, Q.M., GORDON, J. C.D., ALLEN, P.LeG. and ROTTON, N. 1979. The Report of Cambridge Azores Expedition 1979. University of Cambridge, Cambridge, England. $[i-i i]+1-46+$ Checklist [i-iii] + Figs. 1-6 + pls. 1-5 + Appendix 3, Figs. 1-3.

COOK, J.A. 1926. Pursuing The Whale. A Quarter-Century of Whaling in the Arctic. Boston and New York: Houghton Mifflin Company. Frontis + i-xii $+1-344+15$ pls.

CURTIS, E.S. 1916 [1970]. The North American Indian being a series of volumes picturing and describing the Indians of the United States, the Dominion of Canada, and Alaska. Vol. 11: i-xiv + $1-235+76$ pls. [Reprinted: Johnson Reprint Corporation, New York and London].

DAVIDSON, A. n.d. Eskimo Hunting of Bowhead Whales.. Rural Alaska Community Action Program, Anchorage. 37 p. + pls.

DONNELLEY, B.G. 1969. Further observations on the Southern Right Whale, Eubalaena australis, in South African waters. Journal of Reproductive Fertility, Supplement 6:347-352 + pls. 1-2.

DRIVER, H.E. and MASSEY, W.C. 1957. Comparative studies of North American Indians. Transactions of the American Philosophical Society. New Series 47, Pt. 2:163-456. 
DRUCKER, P. 1951. The Northern and Central Nootkan Tribes. Smithsonian Institution. Bureau of American Ethnology Bulletin 144. Government Printing Office, Washington. $\mathrm{i}-[\mathrm{x}]+1-480+5$ pls. + 1 folding map.

DURHAM, F.E. 1974. Ancient and Current Methods of Taking the Bowhead Whale. Alaska Sea Grant Report No. 73-9. University of Alaska, Anchorage. 1-15.

1979. The catch of bowhead whales (Balaena mysticetus) by Eskimos, with emphasis on the western Arctic. Natural History Museum of Los Angeles County, Contributions In Science, No. 314:1-14.

EVANS, C.D. and UNDERWOOD, L.S. 1978. How many bowheads? Oceanus 21(2):17-23.

FENGER, F.A. 1913, , Longshore whaling in the Grenadines. The Outing Magazine 62:664-679.

FISCUS, C.H. and MARQUETTE, W.M. 1975. National Marine Fisheries Service Field Studies Relating to the Bowhead Whale Harvest in Alaska, 1974. NOAA, Northwest Fisheries Center Processed Report January 1975. 23 p.

GASKIN, D.E. and SMITH, G.J.D. 1977. The Small Whale Fishery of St. Lucia, W. I. Cambridge. Report of the International Whaling Commission 27:493.

GRUENING, E.H. 1942. Strategic Alaska looks ahead. National Geographic Magazine 82(3):281315.

HALL, C.F. 1954. Life With the Esquimaux: the narrative of Captain Charles Francis Hall, of the whaling barque "George Henry," from the 29th May, 1860, to the 13th September, 1862. London: Sampson Low, Son, and Marston, 14, Ludgate Hill. Vol. 1:i-xvi + 1-324 + folding map. Vol. 2:i-xii + 1-352.

HEIZER, R.F. 1938. Aconite Poison Whaling in Asia and America: an Aleutian Transfer to the New World. Smithsonian Institution, Bureau of American Ethnology Bulletin 133. Anthropological Papers 24:415-468 + 7 pls.

1968. A bibliography of aboriginal whaling. Journal of the Society for the Bibliography of Natural History 4(7):344-362.

HOUSBY, T. 1971. The Hand of God. Whaling in the Azores. London, New York and Toronto: Abelard-Schuman. $96 \mathrm{p}$.

JOHNSON, M.L., FISCUS, C.H., OSTENSON, B.T. and BARBOUR, M.L. 1966. Marine Mammals. In: Wilimovsky, N.J. and Wolfe J.N., [eds.]. Environment of the Cape Thompson Region, Alaska. Oak Ridge, Tennessee: U.S. Atomic Energy Commission. 877-924.

KAPEL, F.O. 1975. Preliminary notes on the occurrence and exploitation of smaller Cetacea in Greenland. Journal of the Fisheries Research Board of Canada 32(7):1079-1082. 1977a. Catch of Belugas, Narwhals and Harbour Porpoises in Greenland, 1954-75, by Year, Month and Region. Cambridge. Report of the International Whaling Commission 27:507-522. 1977b. Catch Statistics for Minke Whales, West Greenland, 1954-74. Cambridge. Report of the International Whaling Commission 27:456-459.

1978. Catch of Minke Whales by Fishing Vessels in West Greenland. Cambridge. Report of the International Whaling Commission 28:217-226.

1979. Exploitation of Large Whales in West Greenland in the Twentieth Century. Cambridge. Report of the International Whaling Commission 29:197-214.

. and PETERSEN, R. 1979. Subsistence Hunting - The Greenland Case. In: Anonymous. 1979. Reports and documents from Panel Meeting of Experts on Aboriginal/Subsistence Whaling. Seattle, Washington, February 5-9, 1979. 1-50 + figs.

LANTIS, M. 1938. The Alaskan Whale Cult and its affinities. American Anthropologist 40(3):438464.

MAHER, W.J. 1960. Recent records of the California grey whale (Eschrichtius glaucus) along the north coast of Alaska. Arctic 13(4):257-265.

. and WILIMOVSKY, N.J. 1963. Annual catch of bowhead whales by Eskimos at Point Barrow, Alaska, 1928-1960. Journal of Mammalogy 44(1):16-20.

MARQUETTE, W.M. 1976. Bowhead whale field studies in Alaska, 1975. Marine Fisheries Review 38(8):9-17.

1977. The 1976 catch of bowhead whales (Balaena mysticetus) by Alaskan Eskimos, with a review of the fishery, 1973-1976, and a biological summary of the species. Seattle, U.S. Department of Commerce, NOAA, National Marine Fisheries Service, Northwest and Alaska Fisheries Center Processed Report. 80 p. + figs. and table.

1978. The 1976 catch of bowhead whales, Balaena mysticetus, by Alaskan Eskimos. Marine Fisheries Review 40(11):18-27.

1979. The 1977 catch of bowhead whales (Balaena mysticetus) by Alaskan Eskimos. Cambridge. Report of the International Whaling Commission 29:281-289. 
MAUL, G.E. and SERGEANT, D.E. 1977. New cetacean records from Madeira. Museu Municipal do Funchal, Madeira. Bocagiana 43:1-8.

MEARES, J. 1971 [1967]. Voyages made in the Years 1788 and 1789, from China to the North West Coast of America. 2 Vols. London: Logographic Press. [Reprinted as Bibliotheca Australiana No. 22, N. Israel/Amsterdam. 372 p. +108 p. Appendix + pls. and maps.]

MITCHELL, E. 1975. Porpoise, Dolphin and Small Whale Fisheries of the World. Status and problems. IUCN Monograph No. 3. Morges, Switzerland, International Union for Conservation of Nature and Natural Resources. 129 p.

1977. Initial population size of bowhead whale (Balaena mysticetus) stocks: cumulative catch estimates. International Whaling Commisssion, SC/29/Doc. 33. $113 \mathrm{p} .+$ figs. and tables.

1979. Comments on Magnitude of Early Catch of East Pacific Gray Whale Eschrichtius robustus). Report of the International Whaling Commission 29:307-314.

and REEVES, R.R. In press a. Factors affecting abundance of bowhead whales (Balaena mysticetus) in the Eastern Arctic of North America, 1915-1980. Biological Conservation.

and REVES, R.R. In press b. Catch History and Cumulative Catch Estimates of Initial Population Size of Cetaceans in the Eastern Canadian Arctic. Cambridge. Report of the International Whaling Commission 31.

MORGAN, L. 1973. Ocean mammals are to us what the buffalo was to the Plains Indian. National Geographic 143(3):354-355. 1974. We got a whale! Alaska 40(9):33-38.

MURDOCH, J. 1892. Ethnological Results of the Point Barrow Expedition. In: Ninth Annual Report of the Bureau of Ethnology to the Secretary of the Smithsonian Institution, 1887-88, by J. W. Powell, Director. Washington: U.S. Government Printing Office. 1-441 + pls. 1-2.

1898. The animals known to the Eskimos of northwestern Alaska. American Naturalist 32(382):719-734.

NAKASHIMA, L. 1977. Fall whaling in Barrow. Alaska 43(9):97.

NELSON, R.K. 1969. Hunters of the Northern Ice. Chicago and London: The University of Chicago Press. 429 p. + pls.

OHSUMI, S. 1976. Population assessment of the Californian gray whale. International Commission on Whaling, Report and Papers of the scientific Committee of the Commission 1975. London. 350-359.

OSWALT, W.H. 1967. Alaskan Eskimos. San Francisco: Chandler Publishing Company. 297. p. + pls. + maps.

PAYNE, R. 1976. At home with right whales. National Geographic 149(3): 322-39.

PETERSON, W.J. 1978. A study of the effect of the limit on bowhead whale take by the Eskimos of Arctic Alaska. United States Department of the Interior, Bureau of Indian Affairs, Anchorage, Alaska. 106 p. [As cited in Paper IWC/32/35, International Whaling Commission, 31st Annual Meeting, Brighton, England, July 1980].

RAINEY, F. 1941. Eskimo method of capturing bowhead whales. Journal of Mammalogy 21(3):362. 336 . 1942. Discovering Alaska's oldest Arctic town. National Geographic Magazine 82(3):318-

1947. The Whale Hunters of Tigara. Anthropological Papers of the American Museum of Natural History, New York. 41, Pt. 2: 231-283.

RATHJEN, W.F. and SULLIVAN, J.R. 1970. West Indies Whaling. Sea Frontiers 16(3):130-137.

RAY, D.J. 1975. Early maritime trade with the Eskimos of Bering Strait and the introduction of firearms. Arctic Anthropology 12(1): 1-9.

REEVES, R.R. In press. Spitsbergen bowhead stock: a short review. Marine Fisheries Review 42.

RICE, D.W. and WOLMAN, A.A. 1971. The life history and ecology of the gray whale (Eschrichtius robustus). American Society of Mammalogists, Special Publication No. 3:i-viii + 1-142.

RINK, H. 1877. Danish Greenland. Its people and its products. London: Henry S. King \& Co. $468 \mathrm{p} .+$ pls.

RUGH, D.J. and BRAHAM, H.W. 1979. California Gray Whale (Eschrichtius robustus) Fall Migration Through Unimak Pass, Alaska, 1977: A Preliminary Report. Cambridge. Report of the International Whaling Commission 29:315-320.

RUHEN, O. 1966. Harpoon in my hand. Sydney: Angus and Robertson, Ltd. 183 p. + pls.

SCAMMON, C.M. 1869. On the cetaceans of the western coast of North America. Proceedings of the Academy of Natural Sciences of Philadelphia 21:13-63 + 8 pls.

1874. The Marine Mammals of the north-western coast of North America, described and illustrated: Together with an account of the American whale-fishery. San Francisco: J. H. Carmany \& Co. 320 p. + pls. 
SILHOOK, R. 1978. "The Whale is Healthy." Arctic Coastal Zone Management Newsletter No. $13: 2$.

SLWOOKO, H.V. 1977. Whale hunting by skin boat. Alaska 43(9): 12.

SONNENFELD, J. 1960. Changes in an Eskimo hunting technology, an introduction to implement geography. Annals of the Association of American Geographers 50(2): 172-186.

SPENCER, R.F. 1959. The North Alaskan Eskimo. A study in ecology and society. Smithsonian Institution Bureau of American Ethnology, Bulletin 171. Washington: U.S. Government Printing Office. 490 p. + pls. + figs. + maps.

STEENSBY, H.P. 1917. An Anthropogeographical Study of the origin of the Eskimo culture. Meddelesler om Gronland 53(2): 39-228 + 1 pl. + 1 map.

STEFÁNSSON, V. 1914. The Stefánsson-Anderson Arctic Expedition of the American Museum: preliminary ethnological report. Anthropological Papers of the American Museum of Natural History. Vol. 14, Pt. 1. New York: Published by Order of the Trustees. 475 p. +3 maps.

STORRO-PATTERSON, R. 1979. Sperm whales 7,000: U.S. conservation zero. Oceans 12(5): 2. 1980a. The hunt of gray whales by Alaskan Eskimos: a preliminary review. Revised 1 May 1980. Processed report by the Whale Center, Oakland, California. 33 p.

VAN VALIN, W.B. 1945. Eskimoland Speaks. London: Museum Press Limited, 11 Gower Street, WC1, 202 p. + pls.

VENABLES, B. 1968. Baleia! The Whalers of the Azores. London, Sydney, Toronto: The Bodley Head, 206 p. + pls.

VIBE, C. 1967. Arctic animals in relation to climatic fluctuations. Meddelesler om Grønland 170(5): $1-227$.

WEBER, M. 1902. lets over Walvischvangst in den Indischen Archipel. Rumphius Gedenkboek, Haarlem (Koloniaal Museum). 89-93.

1923. Die cetaceen dr Siboga-Expedition. Vorkommen und fang det cetaceen im IndoAustralischen Archipel. Leiden, Siboga-Expeditie 58: 1-38 + pls. 1-3.

WINN, H.E., EDEL, R.K. and TARUSKI, A.G. 1975. Population estimate of the humpback whale (Megaptera novaeangliae) in the West Indies by visual and acoustic techniques. Journal of the Fisheries Research Board of Canada 32(4): 499-506.

WOLMAN, A.A. and RICE, D.W. 1979. Current Status of the Gray Whale. Cambridge. Report of the International Whaling Commission 29: 275-279.

WORL, R. 1978. The North Slope Inupiat contemporary whaling complex. Paper presented to 2nd International Symposium, Division of Ethnology, Taniguchi Foundation, Osaka, Kyoto and Otsu, Japan, August, 1978. 29 p. [Published 1980 as; The North Slope Inupiat Whaling Complex. In: Kotani, Y. and Workman, W.B. (Eds.). Alaska Native Culture and History. Senri Ethnological studies 4. National Museum of Ethnology, Senri, Osaka, Japan. 305-320.]

\section{APPENDIX}

An earlier draft of the above paper was submitted to the International Whaling Commission at its 32nd annual meeting in Cambridge and Brighton, England, June-July 1980, under the title "Overview of Aboriginal and Subsistence Whale Fisheries, and Analysis of the Alaskan Bowhead Problem" as Doc. SC/32/PS 22.

The Scientific Committee again unanimously recommended that "from a biological point of view the only safe course is for the kill of bowhead whales from the Bering Sea stock to be zero"' (Anon., 1980b). New data on current research and past catches and population abundance (Johnson et al., 1980; Bockstoce and Botkin, 1980b, c; Tillman et al., 1980) and a new simulation model (Braham and Breiwick, 1980) were presented. The model indicated that, even in the absence of further hunting, the Bering Sea stock would decline after 1980 (using "pessimistic"' and "moderate"' assumptions about parameter values) or increase only slowly (using "optimistic" assumptions). Recognizing the likelihood that the Commission would disregard its recommendation of a zero catch limit, the Scientific Committee recommended that any whales killed be sexually immature (less than $12 \mathrm{~m}$ long) "in order to maximise reproduction in the short term" and that the struck-but-lost rate be reduced to as close to zero as possible 
(Anon., 1980b). The biological argument against further hunting of Bering Sea stock bowheads was, if anything, strengthened at this year's meeting of the Scientific Committee. The whale population as well as the culture that depends on it may be trending toward extinction.

The gray whale substitution issue (Storro-Patterson, 1980b) was aired, but no consensus was reached about the feasibility or suitability of replacing all or part of the bowhead catch with gray whales. A summary of 49 known kills of gray whales by Alaskan Eskimos during the past 30 years and a review of the local availability of gray whales, by village, were presented (Marquette and Braham, 1980). The feasibility of taking gray whales is demonstrated by the well documented historic catch. Marquette and Braham (1980) indicated that gray whales are "of subsistence value especially the meat, muktuk and sinew." Remaining obstacles to gray whale substitution are local availability and cultural acceptability. Table 3 of Marquette and Braham (1980) indicates that gray whales are "predictably" or "frequently" available to the hunters south of Cape Lisburne at Gambell, Savoonga, Diomede Island, Wales, and Point Hope, and "occasionally" to those north of Cape Lisburne at Wainwright and Barrow. The question of the future cultural acceptability of gray whales will be answered by the native people themselves. However, given the recent and continuing decline of certain important subsistence resources (e.g. caribou and bowhead whales), the hunters may soon have little choice but to turn increasingly to species like the gray whale if they wish to maintain a traditional lifestyle.

The U.S. delegation, having consulted on the matter with domestic government agencies and non-governmental organizations (Anon., 1980c), tabled an unauthored document called "Interim Report on Aboriginal/Subsistence Whaling of the Bowhead Whale by Alaskan Eskimos" (Anon., 1980d). It purports to document and quantify the needs of Alaskan Eskimos for bowhead whales, and was the main Commission document available to the Technical and Plenary sessions as background. Three sets of calculations yielded the following estimates of need: 18 to 22 whales per year based on "cultural needs," 19 to 33 whales per year based on "historic needs," and 32 to 33 whales per year based on "nutritional needs." A "rolling average quota," to be "applied on the basis of a three-year average, with limited variation from a year-to-year basis being allowed, and a credit being added or deducted, as appropriate to the next year's quota," was proposed (Anon., 1980d). This principle was accepted by the Commission, which voted for a quota of 45 total landed ( 17 maximum in a given year) and 65 total struck for the years 1981-1983, inclusive.

It is surprising that the important decision of assigning a quota to the Bering Sea stock of bowhead whales was made mainly on the basis of a document (Anon., 1980d) so strongly biased, badly written, and poorly documented. Of the 15 references cited, only one is in a formal publication, and that one is a popular article! The Commission's failure to subject this document to critical review testifies eloquently to the need for what we have called "suitable" machinery for gathering and evaluating non-biological data" (see our paper above). If the IWC is ever to be capable of managing "aboriginal" or "subsistence" fisheries, it must develop a means of evaluating questions that are cultural, social, and 
technical in nature, and any management group or advisory committee formed to that end must be comprised, as is the present Scientific Committee, of qualified experts in the appropriate fields. [The Seattle workshop reports on aboriginal whaling remain unpublished by the IWC (Anon., 1979c, cited above). So too does the report of the "Technical Committee Working Group on Subsistence/Aboriginal Whaling" (Anon., 1979e), which apparently was not accepted or acted upon by the IWC. Meantime, the Technical Committee (Anon., 1980e) recommended in 1980 that yet another ad hoc "Working Group on Subsistence Whaling"' be convened to generate new findings for consideration at the 1981 IWC meeting.]

Several inconsistencies in Anon. (1980d) could have particularly insidious consequences. Specifically, reference is made to "particular nutrients" provided by the bowhead which, by implication, cannot be acquired from other species. As indicated in our paper above, the Nutritional Panel (Anon., 1979c) had explicitly refuted such a claim.

Further, the Eskimos are said to need more bowheads due to the reduced availability of caribou (Anon., 1980d). We consulted with J.L. Davis of the Alaska Department of Fish and Game, Fairbanks (pers. comm., October 8, 1980) on the recent and present status of caribou populations available to whaling villages in northern Alaska. A brief summary of his findings (Davis, 1978; in press; Davis et al., in press) may be useful.

Most of those mainland whaling villages that rely extensively on caribou hunt the Western Arctic herd. Kaktovik, which hunts the Porcupine herd, and Nuiqsut, which hunts the Western Arctic herd and the small Central Arctic and Teshekpuk herds, are exceptions. The Porcupine herd apparently has remained fairly stable for the last two decades, numbering on the order of 100000 animals. It is not clear that the Kaktovik hunters have suffered from a reduced availability of caribou. The Western Arctic herd has been much more variable. It numbered several hundred thousand during the early 1960 's, with a reliable estimate of 242000 for 1970 . By 1975 it had declined to about 100000 , and by 1976 to 75000 . In 1977 (i.e. regulatory year $1977=1$ July 1976 through 30 June 1977) human exploitation was restricted to the taking of about 3000 male caribou, down from approximately 25000 of either sex taken per year during the early 1970's. This conservative management policy has been continued, and it apparently has made a marked difference in the condition of the herd, allowing it to recover to about 140000 in 1980 . In addition to lowered exploitation by humans, wolf predation apparently has decreased, and conditions for caribou overwintering have been good for the last few years. Although other factors may have contributed to the dramatic decline of the Western Arctic herd during the early 1970's, over-hunting for "subsistence" appears to have been the primary cause (Davis et al., in press). The saving of the caribou herds at the expense of the bowhead stock is not a rational approach, but neither is the sacrificing of the caribou herds in favor of bowhead conservation. A balanced management regime is needed, and this may require restrictions on both caribou hunting and bowhead whaling.

Citing another unauthored U.S. government document as its authority, Anon. (1980d) declares the gray whale "unsuitable for making muktuk because of the 
barnacles." The barnacles generally concentrate in limited areas on the rostrum, lips, sides of the neck, flippers, and tail peduncle; they are most abundant on the areas exposed to air when the whale surfaces (Rice and Wolman, 1971, cited above). "There are few barnacles on the other parts of the body" (Kasuya and Rice, 1970). While gray whale muktuk may be "less desirable" than that of bowheads (Marquette, 1979, cited above), it does have "subsistence value" (Marquette and Braham, 1980). If subsistence fare is as scarce as Anon. (1980d) would have us believe, then it seems curious that palatability ("the meat of the gray whale is not as tasty as that of the bowhead" [Anon., 1980d]) would rate so high as a reason for rejecting out of hand an abundant and nutritionally equivalent substitute for a dwindling subsistence resource.

Much has been made of the "traditional" or "historic" needs of villages such as Kaktovik and Kivalina for bowhead whales, but even the documented "Historic Take/Known Catches" (Anon., 1980d: Table 3) shows only two whaling village complexes in the 1930s (sic), with the addition of Wainwright in the 1940s and Gambell in the 1950s (sic). In the proud history of a people associated with the whale hunt for at least a millenium, can one or two decades, perhaps only one human generation, be taken as the "historical basis" for a claim to traditional or historic need? Even in Wales, where there had been a long tradition of whaling (e.g. Bernardi, 1912), most of the expert whalers died in a 1915 influenza epidemic, and active whaling ended (Collins, 1939). Most of the subsequent landings there stemmed from the utilization of drift bowhead carcasses from the struck-but-lost component of the fishery at St. Lawrence Island, 150 miles away (Collins, 1939).

Anon. (1980d) alleges that an annual quota gives the hunters an incentive to hunt under adverse conditions in order to reach the quota. Such hunting supposedly would jeopardize the safety of the hunters and inflate the struck-but-lost rate. In fact, no evidence has been presented to indicate that the recommended quota has influenced hunter behavior in the manner anticipated by Anon. (1980d). There is, however, evidence that the whalers have tried to exceed the IWC quota in order to emphasize their refusal to honor it (Contos, 1980). Although the 1980 IWC quota for total whales struck had already been exceeded in the spring 1980 hunt, the hunters were active in September 1980 (Contos, 1980). A bowhead was killed and landed at Kaktovik on September 14, and the whalers there apparently continued the hunt subsequently.

The unsolved Bowhead Problem persists.

\section{REFERENCES}

ANONYMOUS. 1979e. Technical Committee Working Group on Subsistence/Aboriginal Whaling, Washington, D.C., April 3-5, 1979 [Report]. 8 p. [Available from the International Whaling Commission, Cambridge, England].

ANONYMOUS. 1980b. Report of the Scientific Committee, International Whaling Commission, 32nd Annual Meeting, Brighton, England, July 1980. IWC/32/4. 50 p. + 3 Annexes.

ANONYMOUS. 1980c. Preparations for the 32d International Whaling Commission Meeting. Hearings before the Subcommittee on International Organizations of the Committee On Foreign Affairs, House Of Representatives, Ninety-Sixth Congress, Second Session, April 30 and May 20, 1980. Washington: U.S. Government Printing Office. $155 \mathrm{p}$. 
ANONYMOUS. 1980d. Interim Report on Aboriginal/Subsistence Whaling of the Bowhead Whale by Alaskan Eskimos. International Whaling Commission, 32nd Annual Meeting, Brighton, England, July 1980. IWC/32/35. 29 p.

ANONYMOUS. 1980e. Report of the Technical Committee. International Whaling Commission, 32nd Annual Meeting, Brighton, England, July 1980. IWC/32/5.

BERNARDI, S.R. 1912. Whaling with Eskimos of Cape Prince of Wales. Louisville, KY: The Courier Journal, October 20: 11-12.

BOCKSTOCE, J.R. and BOTKIN, D.B. 1980b. The historical status and reduction of the western Arctic Bowhead Whale (Balaena mysticetus) population by the pelagic whaling industry, 18481914. Final Report to the National Marine Fisheries Service by the Old Dartmouth Historical Society (New Bedford Whaling Museum) under Contract 03-78-M02-0212. International Whaling Commission, 32nd Annual Meeting, June/July 1980, Cambridge. SC/32/PS 16. 120 p.

1980c. Addendum to report: Historical status and reduction of the western Arctic Bowhead Whale (Balaena mysticetus) population by the pelagic whaling industry, 1848-1914. International Whaling Commission, 32nd Annual Meeting, June/July 1980, Cambridge. SC/32/PS 16 Addendum. $42 \mathrm{p}$.

BRAHAM, H.W. and BREIWICK, J.M. 1980. Projections of a decline in the western Arctic population of bowhead whales. International Whaling Commission, 32nd Annual Meeting, Cambridge. England, June/July 1980. SC/32/PS8. 16 p. + figs. + tables.

COLLINS, H.B. Jr. 1939. Exploring frozen fragments of American history. National Geographic Magazine 75(5):633-656.

CONTOS, S.M. [Ed.]. 1980. Marine Mammal News. Washington, D.C.: Nautilus Press Inc. 6(9):18.

DAVIS, J.L. 1978. History and current status of Alaska caribou herds. In: Klein, D.R. and White, R.G. [Eds.]. Parameters of caribou population ecology in Alaska. Proceedings of a Symposium and Workshop. Biological Papers, University of Alaska, Fairbanks, Special Report No. 3. 1-8. In press. Distribution and status of Rangifer tarandus in the U.S.A. In: The Proceedings of the Second International Reindeer and Caribou Symposium held at Røros. Norway, September 1979.

VALKENBURG, P. and REYNOLDS, $H$. In press. Population dynamics of Alaska's Western Arctic Caribou Herd. In: The Proceedings of the Second International Reindeer and Caribou Symposium held at Røros, Norway, September 1979.

JOHNSON, J.H., BRAHAM, H.W., KROGMAN, B.D., MARQUETTE, W.M., SONNTAG, R.M. and RUGH, D.J. 1980. Research conducted on bowhead whales, June 1979 to June 1980: preliminary results. International Whaling Commission, 32nd Annual Meeting, Cambridge, England, June/July 1980. SC/32/PS10. $49 \mathrm{p}$.

KASUYA, T. and RICE, D.W. 1970. Notes on baleen plates and on arrangement of parasitic barnacles of gray whale. The Scientific Reports of The Whales Research Institute, No. 22: 39-43.

MARQUETTE, W.M. and BRAHAM, H.W. 1980. The take and distribution of gray whales in northern Alaska waters. International Whaling Commission, 32nd Annual Meeting, Cambridge, England, June/July 1980. SC/32/PS12. 8 p. + figs. + tables.

STORRO-PATTERSON, R. 1980b. The hunt of gray whales by Alaskan Eskimos: a preliminary review. Revised 1 May 1980. International Whaling Commission, 32nd Annual Meeting, Cambridge, England, June/July 1980. SC/32/PS7. 33 p.

TILLMAN, M.F., BREIWICK, J.M. and CHAPMAN, D.G. 1980. Reanalysis of historical whaling data for the western Arctic bowhead whale population. International Whaling Commission, 32nd Annual Meeting, Cambridge, England, June/July 1980. SC/32/PS6. 9 p. + tables. 